\title{
Evaluation of nitrogen sources in the Urías lagoon system, Gulf of California, based on stable isotopes in macroalgae
}

\section{Evaluación de las fuentes de nitrógeno en el sistema lagunar de Urías, golfo de California, mediante el uso de isótopos estables en macroalgas}

\author{
María Julia Ochoa-Izaguirre ${ }^{1,2}$, Martín Federico Soto-Jiménez ${ }^{3}$ \\ 1 Posgrado en Ciencias del Mar y Limnología del Instituto de Ciencias del Mar y Limnología, Universidad \\ Nacional Autónoma de México, Unidad Académica Mazatlán, Apdo. postal 811, Mazatlán 82040, Sinaloa, \\ México. \\ 2 Facultad de Ciencias del Mar, Universidad Autónoma de Sinaloa, Paseo Claussen s/n, Apdo. postal 610, \\ Mazatlán 82000, Sinaloa, México. \\ ${ }^{3}$ Instituto de Ciencias del Mar y Limnología, Universidad Nacional Autónoma de México (UAM-ICMyL- \\ UNAM), A. P. 811, Mazatlán 82040, Sinaloa, México.
}

* Corresponding author. E-mail: martin@ola.icmyl.unam.mx

\begin{abstract}
The concentrations of chemical forms of nitrogen $(\mathrm{N})$ and their isotopic composition in the water column and the $\delta^{15} \mathrm{~N}$ signals in 738 samples of macroalgae collected during one year across the Urías lagoon system (Mazatlán, Sinaloa, Mexico) were analyzed in order to study the $\mathrm{N}$ sources. The $\delta^{15} \mathrm{~N}$-macroalgae premise is that they register and integrate the variability of $\mathrm{N}$ and may provide time-integrated information about $\mathrm{N}$ pollution. To validate this premise, we applied two models to predict the isotopic variability of $\mathrm{N}$ available in the water column $\left(\delta^{15} \mathrm{~N}-\mathrm{DIN}\right)$ : one is based on a physical mixing balance of $\mathrm{N}$ sources (simple model), and the second includes the effects of the biogeochemical processes on the signals (coupled model, CM). Both models showed significant $R^{2}$, but $\mathrm{CM}$ better explained the $\delta^{15} \mathrm{~N}$-DIN variability. The relation between $\delta^{15} \mathrm{~N}-\mathrm{DIN} \mathrm{CM}_{\mathrm{CM}}$ and $\delta^{15} \mathrm{~N}$-macroalgae also showed a good fit, although lower than expected and with higher dispersion. The multiple $\mathrm{N}$ sources and co-occurring biogeochemical reactions, which produce a mixture of chemical species of $\mathrm{N}$ and of their isotopic compositions, as well as the high diversity of species (45) explained the elevated variability and lack of fit. Even so, $\delta^{15} \mathrm{~N}$ in macroalgae is the most useful available tool to quantify the relative contributions of $\mathrm{N}$ to ecosystems from different sources. Based on Bayesian isotopic mixing models, the main anthropogenic sources of $\mathrm{N}$ to the Urías lagoonal system were domestic effluents (50\%), atmospheric deposition (24\%), and seafood processing plant effluents (21\%), and to a lesser extent, aquaculture effluents (3\%), agriculture runoff (1\%), and oceanic $\mathrm{N}(1 \%)$.
\end{abstract}

Key words: $\delta^{15} \mathrm{~N}$, eutrophication, biogeochemical cycle, NLOAD model, MixSIR.

RESUMEN. Las concentraciones de las formas químicas de nitrógeno $(\mathrm{N})$ y su composición isotópica en la columna de agua y las señales de $\delta^{15} \mathrm{~N}$ en 738 muestras de macroalgas recolectadas durante un año en el sistema lagunar de Urías (Mazatlán, Sinaloa, México) fueron analizadas para estimar las fuentes de $\mathrm{N}$. La premisa sobre el uso de $\delta^{15} \mathrm{~N}$ en macroalgas es que las macroalgas asimilan ${ }^{15} \mathrm{~N}$ en proporción a la disponibilidad y reflejan la fuente de $\mathrm{N}$ de una manera predecible. Para validar esta premisa, se aplicaron dos modelos para la predicción de la variabilidad isotópica del $\mathrm{N}$ en el agua ( $\left.\delta^{15} \mathrm{~N}-\mathrm{NID}\right)$ : el primero se basa en una mezcla física de las fuentes de $\mathrm{N}$ (modelo simple), y el segundo integra los efectos de procesos biogeoquímicos sobre sus señales isotópicas (modelo acoplado, MA). Ambos modelos mostraron valores de $R^{2}$ significativos, pero el MA explicó mejor la variabilidad del $\delta^{15} \mathrm{~N}-\mathrm{NID}$. La relación entre $\delta^{15} \mathrm{~N}-\mathrm{NID}$ MA y $\delta^{15} \mathrm{~N}-$ macroalgas también mostró un buen ajuste, aunque menor al esperado y con una alta dispersión. Las múltiples fuentes de $\mathrm{N}$ y reacciones biogeoquímicas concurrentes, que producen una mezcla compleja de especies químicas de $\mathrm{N}$ y de sus composiciones isotópicas, además de la alta diversidad de especies (45), explicaron la elevada variabilidad y la falta de ajuste. Aun así, la técnica de $\delta^{15} \mathrm{~N}$ en macroalgas es la herramienta más útil que existe para cuantificar las contribuciones relativas de $\mathrm{N}$ a los ecosistemas derivadas de diferentes fuentes. Con base en la resolución de ecuaciones de mezcla isotópica por estadística Bayesiana, las principales fuentes de $\mathrm{N}$ antropogénico en el sistema lagunar de Urías fueron los efluentes domésticos (50\%), el depósito atmosférico (24\%), los efluentes del procesamiento de productos pesqueros (21\%) y, en menor proporción, los efluentes acuícolas (3\%) los escurrimientos agrícolas (1\%) y $\mathrm{N}$ oceánico (1\%).

Palabras claves: $\delta^{15} \mathrm{~N}$, eutrofización, ciclo biogeoquímico, modelo NLOAD, MixSIR. 


\section{INTRODUCTION}

Nitrogen (N) is considered the nutrient that most frequently limits primary productivity in coastal waters (Nixon 1995). Anthropogenic activities have increased $\mathrm{N}$ inputs to coastal ecosystems and thus altered the biogeochemical cycles in these ecosystems with environmental and ecological consequences (McClelland and Valiela 1998, Savage 2005). Over the past few decades, the natural availability of $\mathrm{N}$ in coastal ecosystems of the Gulf of California (Mexico) has changed due to the substantial increase in human-caused N deposition (Soto-Jiménez et al. 2003a, Piñón-Gimate et al. 2009). The Urías lagoon system is one of the ecosystems most affected by anthropogenic $\mathrm{N}$ inputs, as evidenced by the progressive eutrophication (OchoaIzaguirre et al. 2002).

Stable $\mathrm{N}$ isotopes $\left({ }^{14} \mathrm{~N},{ }^{15} \mathrm{~N}\right)$ in macroalgae have become a useful tool for identifying $\mathrm{N}$ sources in coastal ecosystems (e.g., Deutsch and Voss 2006, Dailer et al. 2010, Kaldy 2011, Ricaurte-Villota et al. 2013). The basic premise of the method is that the ${ }^{15} \mathrm{~N}$ of exposed macroalgae reflects the $\mathrm{N}$ source in a predictable manner (Cohen and Fong 2005). In this study, we quantified the $\mathrm{N}$ sources to the Urías lagoon system (Mazatlán, Sinaloa, Mexico) and measured their chemical and isotopic compositions, and related them to the spatiotemporal variation of the concentrations and chemical forms of $\mathrm{N}$ in the water column. We also compared the variations in the isotopic composition of $\mathrm{N}$ in water with those recorded in macroalgae from the same ecosystem.

\section{MATERIALS AND METHODS}

\section{Study area}

The Urías lagoon system is located at the entrance to the Gulf of California (fig. 1) and covers an area of 1800 ha (Montaño-Ley et al. 2008). The region has a tropicalsubtropical climate and three seasons: rainy from July to October, dry-cold from November to April, and dry-warm from May to June. The lagoon system has three different habitats classified according to salinity: lagoonal habitat ( $\mathrm{LH}$, saline [salinity < 30] and hypersaline [salinity > 36]), lagoonal-marine habitat ( $\mathrm{LMH}$, salinity of 30 to 34), and marine habitat $(\mathrm{MH}$, salinity of $35 \pm 1)$.

The three habitats (fig. 1) can also be associated with the diverse human activities carried out in the area: (1) the upper zone, LH, which is covered by mangroves and influenced by tide channels, receives greater freshwater inputs from streams and agricultural lands (8100 ha), as well as aquaculture effluents (>400 ha) and domestic wastewater discharges; (2) the intermediate zone, LMH, which comprises most of the system and is where the Mazatlán thermoelectric power plant (capacity of $600 \mathrm{MW}$ ) and fishing

\section{INTRODUCCIÓN}

El nitrógeno $(\mathrm{N})$ es considerado el nutriente que limita con mayor frecuencia la productividad primaria en las aguas costeras (Nixon 1995). Las actividades antropogénicas han incrementado los aportes de $\mathrm{N}$ a los ecosistemas costeros, alterando el ciclo biogeoquímico en estos ecosistemas con consecuencias ambientales y ecológicas (McClelland y Valiela 1998, Savage 2005). En las últimas décadas ha ocurrido una alteración en la disponibilidad natural de $\mathrm{N}$ en los ecosistemas costeros del golfo de California (México) debido a que se han incrementado sustancialmente los aportes de $\mathrm{N}$ por actividades humanas (Soto Jiménez et al. 2003a, PiñónGimate et al. 2009). El sistema lagunar de Urías es uno de los ecosistemas más impactados por el aporte antropogénico de $\mathrm{N}$, lo cual es evidenciado por la eutrofización progresiva (Ochoa-Izaguirre et al. 2002).

El uso de los isótopos estables de $\mathrm{N}\left({ }^{14} \mathrm{~N},{ }^{15} \mathrm{~N}\right)$ en macroalgas se ha convertido en una herramienta útil para identificar las fuentes de $\mathrm{N}$ en los ecosistemas costeros (e.g., Deutsch y Voss 2006, Dailer et al. 2010, Kaldy 2011, Ricaurte-Villota et al. 2013). La premisa fundamental de la técnica es que las macroalgas expuestas asimilan ${ }^{15} \mathrm{~N}$ en proporción a la disponibilidad y reflejan la fuente de $\mathrm{N}$ de una manera predecible (Cohen y Fong 2005). En este estudio, se realizó la cuantificación de las cargas de $\mathrm{N}$ que llegan al sistema lagunar de Urías (Mazatlán, Sinaloa, México) y su caracterización química e isotópica, y se relacionaron con la variación espaciotemporal de las concentraciones y formas químicas del $\mathrm{N}$ disponibles en la columna de agua. Además, se compararon las variaciones de la composición isotópica del $\mathrm{N}$ en el agua con las registradas en las macroalgas del ecosistema.

\section{MATERIALES Y MÉTODOS}

\section{Área de estudio}

El sistema lagunar de Urías se localiza en la entrada al golfo de California (fig. 1) y cubre una superficie de 1800 ha (Montaño-Ley et al. 2008). El clima de la región es tropicalsubtropical y presenta un patrón que define tres épocas: lluviosa de julio a octubre, seca-fría de noviembre a abril y seca-cálida de mayo a junio. El sistema lagunar tiene tres hábitats que se clasifican según la salinidad: hábitat lagunar (HL, salobre [salinidad < 30] e hipersalino [salinidad $>36$ ]), hábitat lagunar-marino (HLM, salinidad de 30 a 34) y hábitat marino (HM, salinidad de $35 \pm 1$ ).

Los tres hábitats (fig. 1) también se pueden asociar con las actividades humanas que se desarrollan en los alrededores: (1) la zona superior, HL, que está cubierta por manglar e influenciada por canales de marea, recibe los mayores aportes de agua dulce de los escurrimientos terrestres y de tierras agrícolas (8100 ha), así como de efluentes acuícolas ( $>400 \mathrm{ha}$ ) y aguas residuales domésticas; (2) la zona intermedia, HLM, que comprende la mayor parte del sistema y es donde se localiza la planta termoeléctrica de Mazatlán 
boat docks are located, receives the effluents discharged by seafood processing plants (tuna canning, fishmeal production, shrimp freezing), domestic wastewater discharges (partially and untreated sewage of close to 170,000 inhabitants), and rainfall runoff from one third of the Mazatlán area; and (3) the marine zone, $\mathrm{MH}$, which includes the mouth of the navegation channel (where tourist, merchant, and fishing vessels concentrate) and adjacent offshore waters, receives atmospheric deposition resulting from the emissions from fossil fuel combustion in vehicles and from the thermoelectric plant.

\section{Collection of samples}

Effluent, water column, and macroalgal samples were collected monthly from February 2009 to March 2010 at 20 sites. At each site, we collected 5 to 6 specimens of each species of macroalga found and $4 \mathrm{~L}$ of seawater and effluent. A total of 738 macroalgal specimens and close to 250 water and effluent samples were obtained. In situ temperature (T), salinity (S), dissolved oxygen (DO), and $\mathrm{pH}$ measurements were taken with a YSI $6600 \mathrm{~V} 2$ sensor. The residence time $(\tau)$ (capacidad $600 \mathrm{MW}$ ) y los muelles para la flota pesquera, recibe las descargas de aguas residuales de las industrias que procesan alimentos marinos (enlatado de atún, producción de harina de pescado y congelación de camarón), las descargas de aguas residuales domésticas (parcialmente tratadas y sin tratar de cerca de 170,000 habitantes) y los escurrimientos de agua de lluvia de una tercera parte del área de Mazatlán; y (3) la zona marina, HM, que incluye la boca del canal de navegación (donde se concentra la flota naviera turística, mercante y pesquera), la boca de entrada al puerto y el mar adyacente al sistema, recibe el depósito atmosférico derivado de la quema de combustibles fósiles de vehículos y emisiones de la planta termoeléctrica.

\section{Recolección de muestras}

Las muestras de efluentes, de la columna de agua y de macroalgas fueron recolectadas mensualmente de febrero de 2009 a marzo de 2010 en 20 sitios. En cada sitio se recolectaron de 5 a 6 especímenes de cada especie de macroalga presente y $4 \mathrm{~L}$ de agua de la columna y de cada efluente. En total se recolectaron 738 especímenes y cerca de 250 muestras de agua y efluentes. Se tomaron datos in situ de temperatura (T),

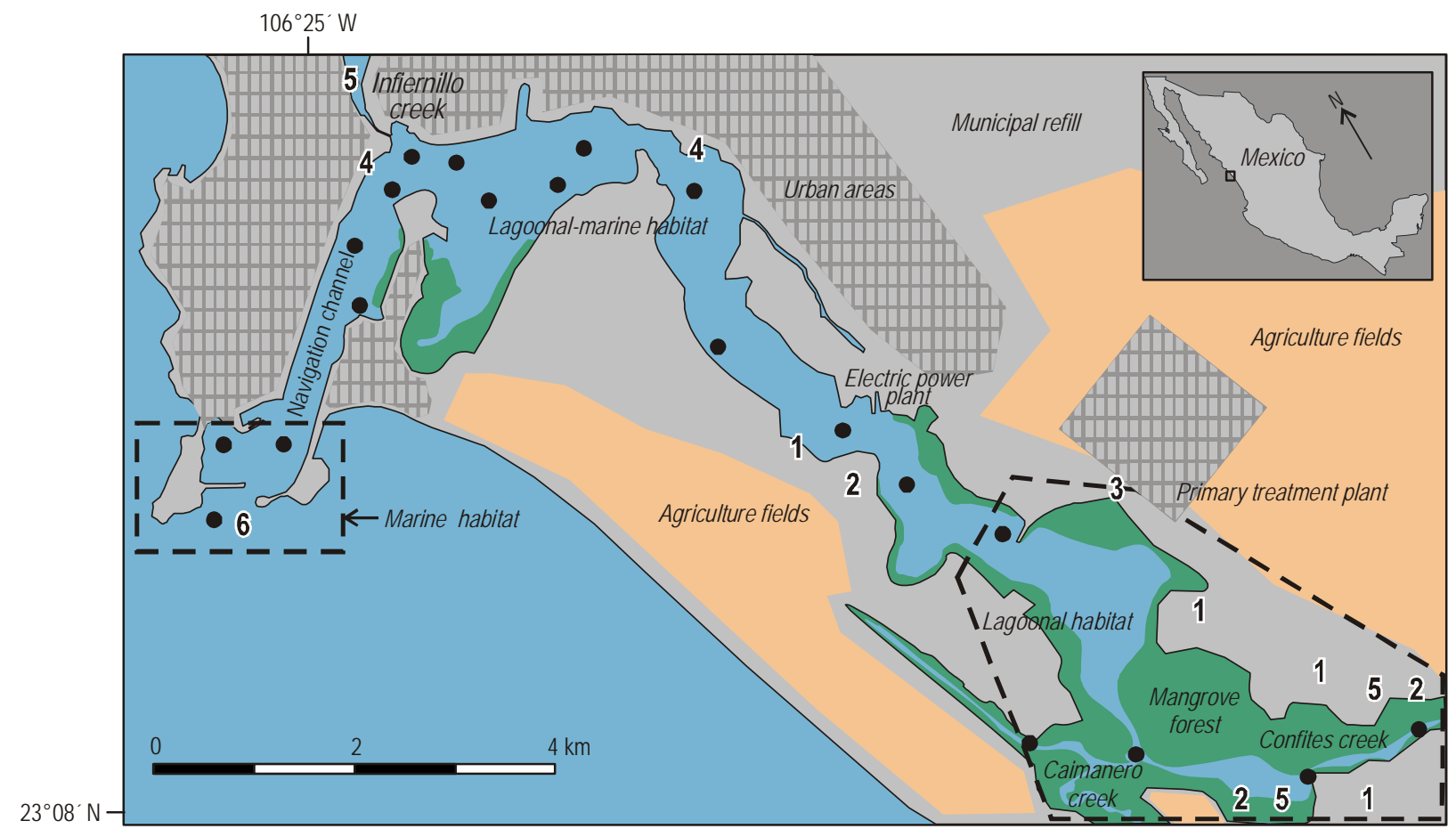

Figure 1. Location of sampling sites (filled circles) and indication of the anthropogenic activities identified as potential sources of nitrogen to the Urías lagoon system (Mazatlán, Sinaloa, Mexico). Potential nitrogen sources: 1, shrimp farm effluents; 2, agriculture effluents; 3, primary wastewater treatment plant effluents; 4 , seafood processing plant effluents; 5 , urban and rural runoff; and 6, adjacent marine waters. Dashed lines indicate the limits of the habitats under study.

Figura 1. Localización de los sitios de muestreo (círculos rellenos) e indicación de las actividades antropogénicas identificadas como fuentes potenciales de nitrógeno al sistema lagunar de Urías (Mazatlán, Sinaloa, México). Fuentes potenciales de nitrógeno: 1, efluentes de granjas de camarón; 2, efluentes agrícolas; 3 , efluentes de planta de tratamiento primario de aguas residuales; 4, efluentes de planta de procesamiento de productos pesqueros; 5 , escurrimiento de áreas urbanas y rurales; y 6, agua marina adyacente. Las líneas discontinuas definen los hábitats estudiados. 
of water in the lagoon system was also modelled (MontañoLey et al. 2008).

In the laboratory, the water and effluent samples were filtered through nitrogen-free Whatman GF/F filters $(0.70 \mu \mathrm{m})$. The filtered water was examined for total dissolved nitrogen (TDN), by complete oxidation to nitrates following Grassoff et al. (1983), and for ammonium $\left(\mathrm{NH}_{4}{ }^{+}\right)$, nitrate $\left(\mathrm{NO}_{3}^{-}\right)$, and nitrite $\left(\mathrm{NO}_{2}^{-}\right)$, according to the methods described by Strickland and Parsons (1972). Dissolved inorganic nitrogen (DIN) was obtained by adding the concentrations of $\mathrm{NH}_{4}^{+}, \mathrm{NO}_{3}^{-}$, and $\mathrm{NO}_{2}^{-}$, whereas dissolved organic nitrogen (DON) was calculated as the difference between TDN and DIN. The detection limits were $0.6 \mu \mathrm{g} \mathrm{L}^{-1}$ for $\mathrm{NH}_{4}{ }^{+}$ and $1 \mu \mathrm{g} \mathrm{L}^{-1}$ for $\mathrm{NO}_{3}^{-}$and $\mathrm{NO}_{2}^{-}$, with a coefficient of variation of $12.4-15 \%$ for all three. Since the concentration of $\mathrm{NO}_{2}^{-}$represents a very small fraction of DIN, it was added to that of $\mathrm{NO}_{3}^{-}$.

Depending on the dominant inorganic $\mathrm{N}$ forms in the filtered effluent and water samples, $\mathrm{NO}_{3}{ }^{-}$and/or $\mathrm{NH}_{4}{ }^{+}$were isolated by diffusion according to the methods proposed by Sigman et al. (1997) and Holmes et al. (1998). To determine $\delta^{15}{\mathrm{~N}-\mathrm{NH}_{4}}^{+}, \mathrm{NH}_{4}{ }^{+}$was converted to $\mathrm{NH}_{3}$ under alkaline conditions. To determine $\delta^{15} \mathrm{~N}_{-} \mathrm{NO}_{3}^{-}, \mathrm{NO}_{3}{ }^{-}$was reduced to $\mathrm{NH}_{4}{ }^{+}$ and converted to $\mathrm{NH}_{3}$ under alkaline conditions. $\mathrm{NH}_{3}$ is transported by diffusion and retained in the GF/D filters. For the isolation of $\mathrm{NH}_{4}{ }^{+}$and/or $\mathrm{NO}_{3}{ }^{-}$, we used standards prepared with artificial seawater containing salts corresponding to the chemical forms and in the concentration ranges of the samples analyzed $(5,10,50$, and $100 \mu \mathrm{M})$ and blanks of Milli-Q water containing all the reagents except the nutrient. To estimate fractionation during the diffusion process, the GF/D filters of the standards and the 1-mg replicates of $\mathrm{KNO}_{3}$ and $\mathrm{NH}_{4} \mathrm{Cl}$ were analyzed by determining the $\mathrm{N}$ content and isotopic composition. Fractionation by diffusion $\left(\Delta^{15} \mathrm{~N}_{\text {diffusion }}\right)$ was calculated by the simple difference between the original isotopic relation of the salt and the resulting relation in the standard after diffusion. The efficiency of the $\mathrm{NH}_{4}{ }^{+}$and $\mathrm{NO}_{3}$ extraction process was estimated by $\mathrm{N}$ recovery in the standard or the sample retained by the GF/D filter. Only recoveries greater than $80 \%$ were accepted and corrected as follows (Holmes et al. 1998):

$$
\Delta \Delta^{15} \mathrm{~N}_{\text {diffusion }}=0.2[\% \text { recovery }]-19.95
$$

Macroalgae were rinsed with Milli-Q water to remove epibionts and freeze-dried $\left(-44^{\circ} \mathrm{C}, 33-72 \mathrm{~mm} \mathrm{Hg}, 72 \mathrm{~h}\right)$. A sample of $5 \mathrm{mg}$ of each dry and ground macroalga was placed in a $6 \times 4 \mathrm{~mm}$ tin vial. The filters with the trapped $\mathrm{N}$ were packed in $9 \times 5 \mathrm{~mm}$ tin capsules and sent, together with the macroalgal samples, to the Stable Isotope Facility at the University of California, Davis, for isotopic analysis. The salinidad (S), oxígeno disuelto (OD) y $\mathrm{pH}$ con una sonda YSI $6600 \mathrm{~V} 2$. También se modeló el tiempo de residencia $(\tau)$ del agua del sistema lagunar (Montaño-Ley et al. 2008).

En el laboratorio, las muestras de agua y efluentes se filtraron con filtros Whatman $\mathrm{GF} / \mathrm{F}(0.70 \mu \mathrm{m})$ libres de $\mathrm{N}$. Al agua filtrada se le determinó la concentración de $\mathrm{N}$ disuelto total (NDT), por oxidación completa a nitratos según Grassoff et al. (1983), y de amonio $\left(\mathrm{NH}_{4}{ }^{+}\right)$, nitrato $\left(\mathrm{NO}_{3}^{-}\right)$y nitrito $\left(\mathrm{NO}_{2}{ }^{-}\right)$, según las técnicas descritas por Strickland y Parsons (1972). El nitrógeno inorgánico disuelto (NID) se obtuvo como la suma de $\mathrm{NH}_{4}{ }^{+}, \mathrm{NO}_{3}^{-}{\text {y } \mathrm{NO}_{2}-}^{-}$, mientras que el nitrógeno orgánico disuelto (NOD) se calculó como la diferencia entre el NDT y el NID. El límite de detección de $\mathrm{NH}_{4}{ }^{+}$ fue de $0.6 \mu \mathrm{g} \mathrm{L}-1$ y el de $\mathrm{NO}_{3}^{-}$y $\mathrm{NO}_{2}^{-}$fue de $1 \mu \mathrm{g} \mathrm{L}^{-1}$, con un coeficiente de variación de $12.4-15 \%$ para las tres formas químicas. Debido a que la concentración de $\mathrm{NO}_{2}{ }^{-}$representa una fracción muy baja del NID, se sumó a la de $\mathrm{NO}_{3}^{-}$.

Dependiendo de las formas inorgánicas de $\mathrm{N}$ dominantes en las muestras filtradas de los efluentes y de la columna de agua, se aisló el $\mathrm{NO}_{3}^{-}$y/o $\mathrm{NH}_{4}{ }^{+}$por difusión siguiendo los métodos propuestos por Sigman et al. (1997) y Holmes et al. (1998). Para determinar el $\delta^{15} \mathrm{~N}_{-} \mathrm{NH}_{4}{ }_{4}$, se convirtió el $\mathrm{NH}_{4}{ }^{+}$a $\mathrm{NH}_{3}$ bajo condiciones alcalinas. Para determinar el $\delta^{15} \mathrm{~N}-$ $\mathrm{NO}_{3}{ }^{-}$, se realizó una reducción total del $\mathrm{NO}_{3}{ }^{-}$a $\mathrm{NH}_{4}{ }^{+}$y su posterior conversión a $\mathrm{NH}_{3}$ bajo condiciones alcalinas. El $\mathrm{NH}_{3}$ es transportado por difusión y capturado en los filtros GF/D. Para el aislamiento de $\mathrm{NH}_{4}^{+}$y/o $\mathrm{NO}_{3}^{-}$, se incluyeron estándares preparados con agua de mar artificial que contenía sales correspondientes a las formas químicas y en los intervalos de las concentraciones de las muestras analizadas $(5,10$, 50 y $100 \mu \mathrm{M})$ y blancos con agua Milli-Q que contenían todos los reactivos excepto el nutriente. Para calcular el fraccionamiento durante el proceso de difusión, se analizaron los filtros GF/D de los estándares y las réplicas de $1 \mathrm{mg}$ de $\mathrm{KNO}_{3}$ y $\mathrm{NH}_{4} \mathrm{Cl}$ para determinar el contenido de $\mathrm{N}$ y la composición isotópica. El fraccionamiento por difusión $\left(\Delta^{15} \mathrm{~N}_{\text {difusión }}\right)$ se calculó por medio de una simple diferencia entre la relación isotópica original de la sal y la relación resultante en el estándar después de la difusión. La eficiencia del proceso de extracción de $\mathrm{NH}_{4}{ }^{+}$y $\mathrm{NO}_{3}{ }^{-}$se estimó como la recuperación del $\mathrm{N}$ en el estándar o en la muestra capturada en el filtro GF/D. Sólo las recuperaciones mayores que $80 \%$ fueron aceptadas y corregidas como sigue (Holmes et al. 1998):

$$
\Delta{ }^{15} \mathrm{~N}_{\text {difusión }}=0.2[\% \text { de recuperación }]-19.95
$$

Se enjuagaron las macroalgas con agua Milli-Q para eliminar a los epibiontes y se secaron por liofilización $\left(-44^{\circ} \mathrm{C}, 33-72 \mathrm{mmHg}, 72 \mathrm{~h}\right)$. Se colocó una muestra de $5 \mathrm{mg}$ de cada macroalga seca y molida en viales de estaño de $6 \times 4 \mathrm{~mm}$. Los filtros con el $\mathrm{N}$ atrapado fueron empacados en cápsulas de estaño de $9 \times 5 \mathrm{~mm}$ y se enviaron, junto con las muestras de macroalgas, al Laboratorio de Isótopos Estables de la Universidad de California (Davis) para su análisis 
isotopic values of $\mathrm{N}$ were expressed in parts per thousand with reference to atmospheric $\mathrm{N}$, which is the internationally accepted standard. The $\delta^{15} \mathrm{~N}$ isotopic signals of the analyzed samples were expressed using delta $(\delta)$ notation:

$$
\delta^{15} \mathrm{~N}(\%)=\left(\frac{{ }^{15} \mathrm{~N} /{ }^{14} \mathrm{~N} \text { sample }}{{ }^{15} \mathrm{~N} /{ }^{14} \mathrm{~N} \text { reference }}-1\right) \times 1000
$$

\section{Data processing}

\section{Nitrogen loading model}

The NLOAD model described by Valiela et al. (1997, 2002) was used to identify the $\mathrm{N}$ sources and the total $\mathrm{N}$ load received by the Urías system from the catchment basin. Briefly, NLOAD calculates the N fluxes to a coastal ecosystem from the catchment area considering the land use (natural vegetation, agriculture, urban, parks and gardens, marshes, etc.), the number of inhabitants ( $\%$ of treated sewage and type of treatment), and human activities such as the burning of fossil fuels (vehicular, industrial) and food production (e.g., agriculture, livestock raising, food processing). The model estimates the loss of $\mathrm{N}$ during its transport from the catchment basin to the coastal ecosystem by different processes, such as adsorption, assimilation, volatilization, and denitrification.

\section{Simple and coupled mixing models}

To explain the variability of $\delta^{15} \mathrm{~N}-\mathrm{DIN}$ in water, a physical mixing model was used (simple model) based on an isotopic balance using the concentrations of the inorganic $\mathrm{N}$ forms and their isotopic compositions, according to the source:

$$
\begin{gathered}
\delta^{15} \mathrm{~N}-\mathrm{DIN}=f_{1}\left(\delta_{1}\right)+f_{2}\left(\delta_{2}\right)+\ldots f_{n}\left(\delta_{n}\right) \\
f_{1}+f_{2}+\ldots f_{n}=1
\end{gathered}
$$

where $f_{i}$ is the proportional contribution of source $i$ to the mixture and $\delta_{i}$ is the isotopic signature of source $i$. Since the sources of $\mathrm{NO}_{3}{ }^{-}$are terrestrial (e.g., agriculture, atmospheric) and oceanic, for the prediction of $\delta^{15} \mathrm{~N}-\mathrm{NO}_{3}{ }^{-}$it was first necessary to apply a mixed binary balance (marine and terrestrial) based on salinity to calculate the fraction of seawater (and $\mathrm{NO}_{3}^{-}$), following Middleburg and Nieuwenhuize (2001): isotópico. Los valores isotópicos del $\mathrm{N}$ fueron registrados en partes por mil con referencia al nitrógeno atmosférico, que es el estándar convenido internacionalmente. Las señales isotópicas $\delta^{15} \mathrm{~N}$ de las muestras analizadas fueron registradas usando la notación delta $(\delta)$ :

$$
\delta^{15} \mathrm{~N}(\%)=\left(\frac{{ }^{15} \mathrm{~N} /{ }^{14} \mathrm{~N} \text { muestra }}{{ }^{15} \mathrm{~N} /{ }^{14} \mathrm{~N} \text { referencia }}-1\right) \times 1000
$$

\section{Procesamiento de datos}

\section{Modelo de carga de $N$}

Se utilizó el modelo NLOAD descrito por Valiela et al. (1997, 2002) para identificar las fuentes de N, y se estimó la carga total de $\mathrm{N}$ que recibe el sistema de Urías desde la cuenca de captación. Brevemente, NLOAD calcula las cargas de $\mathrm{N}$ que llegan a un ecosistema costero desde la cuenca de captación considerando el uso de suelo del ecosistema (vegetación natural, agricultura, urbana, parques y jardines, humedales, etc.), el número de habitantes (\% de agua residual tratada y tipo de tratamiento) y las actividades humanas tales como la quema de combustibles fósiles (vehicular, industrial) y producción de alimento (e.g., agricultura, crianza de animales, procesamiento de alimentos). El modelo estima las pérdidas de $\mathrm{N}$ durante su transporte desde la cuenca de captación hasta el ecosistema costero por diferentes procesos, como la adsorción, asimilación, volatilización y desnitrificación.

\section{Modelos de mezcla simple y acoplado}

Para explicar la variabilidad del $\delta^{15} \mathrm{~N}-\mathrm{NID}$ en el agua, se utilizó un primer modelo de mezcla de intercambio físico (modelo simple) basado en un balance isotópico utilizando las concentraciones de las formas inorgánicas de $\mathrm{N}$ y sus composiciones isotópicas, según su fuente de origen:

$$
\begin{gathered}
\delta^{15} \mathrm{~N}-\mathrm{NID}=f_{1}\left(\delta_{1}\right)+f_{2}\left(\delta_{2}\right)+\ldots f_{n}\left(\delta_{n}\right) \\
f_{1}+f_{2}+\ldots f_{n}=1
\end{gathered}
$$

donde $f_{i}$ es la contribución proporcional de la fuente $i$ a la mezcla y $\delta_{i}$ es la firma isotópica de la fuente $i$. Debido a que las fuentes del $\mathrm{NO}_{3}^{-}$son terrestres (e.g., agricultura, atmosférica) y marina, para la predicción del $\delta^{15} \mathrm{~N}-\mathrm{NO}_{3}{ }^{-}$fue necesario primero hacer un balance de mezcla binario (marino y terrestre) basado en la salinidad para calcular la fracción de agua de mar (y de $\mathrm{NO}_{3}^{-}$), de acuerdo con Middleburg y Nieuwenhuize (2001):

$$
\delta^{15} \mathrm{~N}^{-\mathrm{NO}_{3}^{-}}=\left[\left(\delta^{15} \mathrm{~N}-\mathrm{Nm}\right)(f)\left(\delta^{15} \mathrm{~N}-\mathrm{Nm}\right)+\left(\delta^{15} \mathrm{~N}-\mathrm{Nr}\right)(1-f)\left(\delta^{15} \mathrm{~N}-\mathrm{Nr}\right)\right] / \mathrm{N}
$$


where $\delta^{15} \mathrm{~N}^{-\mathrm{NO}_{3}^{-}}, \delta^{15} \mathrm{~N}-\mathrm{Nm}$, and $\delta^{15} \mathrm{~N}-\mathrm{Nr}$ are the isotopic values of $\mathrm{NO}_{3}{ }^{-}$in the water column, the oceanic sample, and the terrestrial sample, respectively.

The sources of $\mathrm{NH}_{4}{ }^{+}$were considered to be anthropogenic activities and the decomposition of organic matter (allochthonous and autochthonous). The marine source was considered negligible due to the low concentrations of $\mathrm{NH}_{4}{ }^{+}$in the adjacent seawater.

Nitrogen is highly reactive and its concentrations, chemical forms, and distinct isotopic composition change systematically as it participates in reactions associated with its biogeochemical cycle (Middleburg and Nieuwenhuize 2001). This isotopic change is called fractionation, and its magnitude depends on the type and intensity of the reaction, which in turn depends on the environmental conditions and time elapsed. Biogeochemical processes such as ammonium volatilization, nitrification, and denitrification result in isotopic fractionation that diverts the signals generated by the simple model relative to those observed in the field. A general linear model (coupled model) was thus designed that considers the effects of these processes on the variability in isotopic ratio (Moore and Semmens 2008):

$$
\delta^{15} \mathrm{~N}-\mathrm{DIN}=f_{1}\left(\delta_{1-\gamma 1}\right)+f_{2}\left(\delta_{2-\gamma 2}\right)+\ldots f_{n}\left(\delta_{n-\gamma n}\right)
$$

where $\gamma_{i}$ is the specific fractionation of source $i$ participating in some biogeochemical process. Although organic matter mineralization is an important source of inorganic $\mathrm{N}$ in the water column, it has no effect on isotopic composition (Kendall 1998). Neither does biological N fixation produce isotopic fractionation (Swart et al. 2008). On the other hand, we assume that $\mathrm{NO}_{3}{ }^{-}$produced by denitrification is associated with the denitrification process (Dollhopf et al. 2005).

\section{Volatilization $\left(\mathrm{V}_{\mathrm{NH} 3}\right)$}

In seawater, the equilibrium of the $\mathrm{NH}_{4}^{+} \rightarrow \mathrm{NH}_{3}$ reaction is mainly affected by $\mathrm{pH}$, and to a lesser extent by $\mathrm{T}$ and $\mathrm{S}$. We thus estimated the fraction of $\mathrm{NH}_{3}\left(\mathrm{x}_{\mathrm{NH} 3}\right)$ produced and removed from the water column, following Spotte and Adams (1983):

$$
\mathrm{x}_{\mathrm{NH} 3}=1+\operatorname{antilog}(\mathrm{pK}-\mathrm{pH})
$$

$$
\mathrm{pK}=\left[0.0902+2727.9 /(\mathrm{T}+273.1)+\left(0.155-3.15 \times 10^{-4}\right)\right][19.973 \mathrm{~S} /(1000-1.2005 \mathrm{~S})]
$$

where $\mathrm{pK}$ is the equilibrium constant of the reaction as a function of $\mathrm{T}$ and $\mathrm{S}$. donde $\delta^{15} \mathrm{~N}^{-\mathrm{NO}_{3}-}, \quad \delta^{15} \mathrm{~N}-\mathrm{Nm}$ y $\delta^{15} \mathrm{~N}-\mathrm{Nr}$ son los valores isotópicos del $\mathrm{NO}_{3}^{-}$en la columna de agua, en la muestra marina y en la muestra terrestre, respectivamente.

Para el caso del $\mathrm{NH}_{4}{ }^{+}$, se consideró que las fuentes fueron antropogénicas y resultado de la descomposición de materia orgánica (alóctona y autóctona). La fuente marina se consideró despreciable debido a las bajas concentraciones de $\mathrm{NH}_{4}{ }^{+}$ en el agua del mar adyacente.

El $\mathrm{N}$ es altamente reactivo y sus concentraciones, sus formas químicas y su composición isotópica distintiva de la fuente de origen cambian sistemáticamente conforme participa en reacciones asociadas a su ciclo biogeoquímico (Middleburg y Nieuwenhuize 2001). Al cambio isotópico se le denomina fraccionación, y su magnitud está en función del tipo e intensidad de la reacción, que a su vez depende de las condiciones ambientales y del tiempo transcurrido. Los procesos biogeoquímicos tales como la nitrificación, desnitrificación y volatilización de amonio resultan en una fraccionación isotópica que desvía las señales generadas por el modelo simple con respecto a las observadas en el campo. Se diseñó un modelo lineal general que considerara los efectos de tales procesos sobre la variabilidad en la proporción isotópica (modelo acoplado) (Moore y Semmens 2008):

$$
\delta^{15} \mathrm{~N}-\mathrm{NID}=f_{1}\left(\delta_{1-\gamma 1}\right)+f_{2}\left(\delta_{2-\gamma 2}\right)+\ldots f_{n}\left(\delta_{n-\gamma n}\right)
$$

donde $\gamma_{i}$ representa la fraccionación específica de la fuente $i$ que resulta de su participación en algún proceso biogeoquímico. Aunque la mineralización de la materia orgánica es fuente importante de $\mathrm{N}$ inorgánico a la columna de agua, no tiene efecto sobre la composición isotópica (Kendall 1998). Tampoco la fijación biológica de $\mathrm{N}$ produce fraccionación isotópica (Swart et al. 2008). Por otro lado, suponemos que el $\mathrm{NO}_{3}{ }^{-}$producido por nitrificación está acoplado al proceso de desnitrificación (Dollhopf et al. 2005).

\section{Volatilización $\left(\mathrm{V}_{\mathrm{NH} 3}\right)$}

El equilibrio de la reacción $\mathrm{NH}_{4}{ }^{+} \rightarrow \mathrm{NH}_{3}$ en el agua de mar se ve afectado principalmente por el $\mathrm{pH}$, y en menor medida por la T y S. Por lo tanto, siguiendo el modelo propuesto por Spotte y Adams (1983), se estimó la fracción de $\mathrm{NH}_{3}\left(\mathrm{x}_{\mathrm{NH} 3}\right)$ producida y removida de la columna de agua:

$$
\mathrm{x}_{\mathrm{NH} 3}=1+\operatorname{antilog}(\mathrm{pK}-\mathrm{pH})
$$

donde $\mathrm{pK}$ es la constante de equilibrio de la reacción en función de la $\mathrm{T}$ y $\mathrm{S}$. 


\section{Denitrification $\left(\mathrm{D}_{\mathrm{NO} 3}\right)$}

The denitrification reaction (CHONP $+\mathrm{HNO}_{3} \rightarrow \mathrm{CO}_{2}+$ $\mathrm{H}_{3} \mathrm{PO}_{4}+\mathrm{H}_{2} \mathrm{O}+\mathrm{N}_{2}$ ) mainly depends on the absence of DO and presence of $\mathrm{NO}_{3}{ }^{-}$, but is also influenced by $\mathrm{T}, \mathrm{pH}$, and $\tau$. The effect of this reaction was estimated by the general denitrification equation (Heinen 2006):

$$
\mathrm{D}_{\mathrm{NO} 3}=\alpha f_{\mathrm{NO} 3} f_{\mathrm{T}} f_{\mathrm{s}} f_{\mathrm{pH}}
$$

where $\alpha$ is the denitrification potential based on DO, according to the following criterion: $\alpha=0$ for $\mathrm{DO} \geq 2 \mathrm{mg} \mathrm{L}^{-1}$ and $\alpha=1$ for $\mathrm{DO}=0 \mathrm{mg} \mathrm{L}^{-1} ; f_{\mathrm{NO} 3}$ refers to the effect of the concentration of $\mathrm{NO}_{3}{ }^{-}$required for the reaction that follows a nonlinear Michaelis-Menten behavior:

$$
f_{\mathrm{NO} 3}=\mathrm{N} /(\mathrm{K}+\mathrm{N})
$$

where $f_{\mathrm{NO} 3}$ is dimensionless and ranges from 0 to $1, \mathrm{~N}$ is the concentration of $\mathrm{NO}_{3}{ }^{-}\left(\mathrm{mg} \mathrm{L}^{-1}\right)$, and $\mathrm{K}$ is the mean saturation constant with a value of $10 \mathrm{mg} \mathrm{L}^{-1}$ for $f_{\mathrm{NO} 3}=0.5$ (Heinen 2006).

Since denitrification is a biological process, the rate of reaction increases exponentially with $\mathrm{T}$ according to the Arrhenius law. Bacterial activity is zero $\left(f_{\mathrm{T}}=0\right)$ at $0{ }^{\circ} \mathrm{C}$ and optimum $\left(f_{\mathrm{T}}=1\right)$ at $20^{\circ} \mathrm{C}$ (Heinen 2006). Optimum $\mathrm{pH}$ for the reaction ranges from 7.0 to $7.5\left(f_{\mathrm{pH}}=1\right)$, the reaction ceasing at $\mathrm{pH}<4$ or $\mathrm{pH}>10\left(f_{\mathrm{pH}}=0\right)($ Heinen 2006). Finally, the magnitude of $\mathrm{NO}_{3}{ }^{-}$loss increases in relation to $\tau$. The fraction of $\mathrm{NO}_{3}^{-}\left(\mathrm{x}_{\mathrm{NO} 3}\right)$ potentially lost by denitrification can be calculated with the general equation (eq. 9).

\section{Model validation}

After estimating the effects of volatilization and denitrification on the $\mathrm{NH}_{4}{ }^{+}$and $\mathrm{NO}_{3}{ }^{-}$signals, respectively, and constructing the simple and coupled models to predict the isotopic signals of DIN, the results were validated using the water column $\delta^{15} \mathrm{~N}^{-} \mathrm{NH}_{4}^{+}$and $\delta^{15} \mathrm{~N}^{-\mathrm{NO}_{3}-}$ values determined by diffusion methods. The model with highest affinity to the values determined in the field by linear regression analysis was selected. The macroalgal $\delta^{15} \mathrm{~N}$ values were plotted in relation to the $\delta^{15} \mathrm{~N}$-DIN signals predicted by the validated model.

\section{Estimating the relative contributions}

The MixSIR program based on Bayesian statistics (Moore and Semmens 2008) was used to solve the mixing models (simple and coupled) constructed to estimate the probable distribution of the contributions of $\mathrm{N}$ sources in the lagoon system. The isotopic composition of $\mathrm{NH}_{4}{ }^{+}$and $\mathrm{NO}_{3}{ }^{-}$
Desnitrificación $\left(\mathrm{D}_{\mathrm{NO} 3}\right)$

La reacción de la desnitrificación (CHONP $+\mathrm{HNO}_{3} \rightarrow$ $\mathrm{CO}_{2}+\mathrm{H}_{3} \mathrm{PO}_{4}+\mathrm{H}_{2} \mathrm{O}+\mathrm{N}_{2}$ ) depende primordialmente de la ausencia de $\mathrm{OD}$ y presencia de $\mathrm{NO}_{3}^{-}$, pero también es influenciada por la $\mathrm{T}$, el $\mathrm{pH}$, y el $\tau$. El efecto de esta reacción se evaluó mediante la ecuación general de la desnitrificación (Heinen 2006):

$$
\mathrm{D}_{\mathrm{NO} 3}=\alpha f_{\mathrm{NO} 3} f_{\mathrm{T}} f_{\mathrm{s}} f_{\mathrm{pH}}
$$

donde $\alpha$ representa el potencial de desnitrificación basado en el OD, según el siguiente criterio: $\alpha=0$ para $\mathrm{OD} \geq 2 \mathrm{mg} \mathrm{L}^{-1}$ y el valor se incrementa hasta $\alpha=1$ cuando $\mathrm{OD}=0 \mathrm{mg} \mathrm{L}^{-1}$; $f_{\mathrm{NO} 3}$ se refiere al efecto de la concentración de $\mathrm{NO}_{3}{ }^{-}$requerido para la reacción que sigue un comportamiento no lineal del tipo Michaelis-Menten:

$$
f_{\mathrm{NO} 3}=\mathrm{N} /(\mathrm{K}+\mathrm{N})
$$

donde $f_{\mathrm{NO} 3}$ es adimensional y varía de 0 a $1, \mathrm{~N}$ es la concentración de $\mathrm{NO}_{3}^{-}\left(\mathrm{mg} \mathrm{L}^{-1}\right)$ y K es la constante media de saturación con un valor de $10 \mathrm{mg} \mathrm{L}^{-1}$ para $f_{\mathrm{NO} 3}=0.5$ (Heinen 2006).

Dado que la desnitrificación es un proceso biológico, la velocidad de reacción se incrementa exponencialmente con la $\mathrm{T}$ según la ley de Arrhenius. La actividad bacteriana es cero $\left(f_{\mathrm{T}}=0\right)$ a una $\mathrm{T}$ de $0{ }^{\circ} \mathrm{C}$ y se incrementa en función de la $\mathrm{T}$ hasta alcanzar su óptimo $\left(f_{\mathrm{T}}=1\right)$ a $20^{\circ} \mathrm{C}$ (Heinen 2006). El $\mathrm{pH}$ óptimo para la reacción varía de 7.0 a $7.5\left(f_{\mathrm{pH}}=1\right)$; la reacción cesa a $\mathrm{pH}<4$ o $\mathrm{pH}>10\left(f_{\mathrm{pH}}=0\right)$ (Heinen 2006). Finalmente, la magnitud de la pérdida de $\mathrm{NO}_{3}{ }^{-}$se incrementa en función de $\tau$. La resolución de la ecuación general (ec. 9) permite calcular la fracción de $\mathrm{NO}_{3}{ }^{-}\left(\mathrm{x}_{\mathrm{NO} 3}\right)$ potencialmente perdida por desnitrificación.

\section{Validación de los modelos}

Una vez que se estimaron los efectos de volatilización y desnitrificación en las señales del $\mathrm{NH}_{4}{ }^{+} \mathrm{y} \mathrm{NO}_{3}^{-}$, respectivamente, y que se resolvieron los dos modelos (simple y acoplado) para predecir las señales isotópicas en el NID, se validaron los resultados con los valores de $\delta^{15} \mathrm{~N}_{-} \mathrm{NH}_{4}{ }^{+}$ y $\delta^{15} \mathrm{~N}^{-N^{-}}{ }_{3}^{-}$determinados en la columna de agua por las técnicas de difusión. Se seleccionó el modelo con mayor afinidad a los valores determinados en el campo mediante un análisis de regresión lineal. Los valores isotópicos $\delta^{15} \mathrm{~N}$ en las macroalgas fueron graficados en función de las señales del $\delta^{15} \mathrm{~N}-\mathrm{NID}$ predichas por el modelo validado.

\section{Estimación de las contribuciones relativas}

La resolución de los dos modelos de mezcla para estimar la probable distribución de las contribuciones de $\mathrm{N}$ al sistema 
in the $\mathrm{N}$ sources and in representative samples of the water column, as well fractionation factors during ammonium volatilization and denitrification $(\gamma)$ were incorporated into solving the models. The relative contributions of the different $\mathrm{N}$ sources to macroalgae were also estimated using their isotopic signals according to their chemical form and the estimated fractionation effects.

\section{RESUlTS}

\section{Nitrogen sources and loading to the system}

We identified five human-related sources of $\mathrm{N}$ that discharge into the Urías system: agricultural runoff, aquaculture effluents, atmospheric deposition, domestic wastewater effluents (sewage), and seafood processing plant (industrial) effluents (table 1). The total $\mathrm{N}$ loads ranged from 692 to $711 \mathrm{t} \mathrm{yr}^{-1}$; atmospheric deposition (29\%) and treated and untreated sewage (28\%) were responsible for the highest $\mathrm{N}$ inputs. The $\mathrm{N}$ load of marine origin, estimated by multiplying the volume of tidal flux for the Urías system by the mean concentration of $\mathrm{N}$ in the adjacent sea, was $94.1 \mathrm{t} \mathrm{yr}^{-1}(13 \%)$; however, $\mathrm{N}$ export was $281 \mathrm{t} \mathrm{yr}^{-1}$. The $\mathrm{N}$ load per unit area of the microbasin and agricultural lands was $25.3 \mathrm{~kg} \mathrm{ha}^{-1} \mathrm{yr}^{-1}$, whereas the $\mathrm{N}$ load entering the Urías system was 384 to $395 \mathrm{~kg} \mathrm{yr}^{-1}$ per hectare of water mirror.

The $\mathrm{N}$ sources reaching the Urías system varied temporarily. During the rainy season, terrestrial leachates from the Urías microbasin and agricultural soil washing were discharged mainly by the channels in the upper zone (LH) and the Infiernillo estuary in the intermediate zone (LMH), in addition to aquaculture effluents from two farms operating in LH (from August to December and April to June). Sewage and industrial effluents discharge into LMH and are relatively constant year-round sources.

The isotopic characterization of the $\mathrm{N}$ sources (table 1) varied from low signals for agricultural runoff $(2.1 \pm 0.70 \%$; mean \pm standard deviation) to very high for treated sewage $(16.1 \pm 0.30 \%)$ and industrial effluents $(19.1 \pm 0.68 \%)$. On average, the signal derived for leachates from the Urías microbasin varied little (1.4-2.8\%), depending on the agricultural land drained. Marine $\mathrm{NO}_{3}^{-}$ranged from $1.9 \%$ to $5.5 \%$ according to the sampling season. Groundwater $\mathrm{N}$ loads were not considered, but we believe that the main $\mathrm{N}$ sources to the aquifer are atmospheric deposition and, to a lesser extent, agricultural runoff to the Mazatlán sub-basin and sewage from suburban and rural areas.

\section{Environmental variables, chemical forms, and isotopic composition of nitrogen}

The spatiotemporal variation of $\mathrm{T}, \mathrm{S}, \mathrm{pH}$, and $\mathrm{DO}$ in the Urías system is summarized in table 2 : T ranged from $22.2 \pm$ 1.5 to $33.6 \pm 0.59^{\circ} \mathrm{C}$; $\mathrm{S}$ ranged from $25.9 \pm 2.5$ to $39.8 \pm 2.8$; mean $\mathrm{pH}$ was $7.81 \pm 0.26$, with minimum and maximum lagunar se realizó con el programa MixSIR basado en estadística Bayesiana (Moore y Semmens 2008). La composición isotópica del $\mathrm{NH}_{4}{ }^{+}$y $\mathrm{NO}_{3}{ }^{-}$en las fuentes de $\mathrm{N}$ y en muestras representativas de la columna de agua, así como los factores de fraccionación por volatilización de amonio y desnitrificación $(\gamma)$, fueron incorporados en la solución de los modelos. También se estimaron las contribuciones relativas de las diferentes fuentes de $\mathrm{N}$ a las macroalgas utilizando sus señales isotópicas según su forma química y los efectos de fraccionación estimados.

\section{RESUltados}

\section{Fuentes y cargas de nitrógeno al sistema}

Se identificaron cinco fuentes antropogénicas de $\mathrm{N}$ que descargan en el sistema de Urías: escurrimientos agrícolas, efluentes acuícolas, depósito atmosférico, aguas residuales domésticas (en adelante aguas residuales) y efluentes del procesamiento de productos pesqueros (tabla 1). Las cargas totales de $\mathrm{N}$ se calcularon entre 692 y $711 \mathrm{t}$ año-1. Los mayores aportes provinieron del depósito atmosférico (29\%) y de las aguas residuales tratadas y sin tratar (28\%). La carga de $\mathrm{N}$ de origen marino, estimada multiplicando el volumen de flujo de marea para el sistema de Urías por la concentración promedio de $\mathrm{N}$ del mar adyacente, fue de $94.1 \mathrm{t}$ año ${ }^{-1}$ (13\%); sin embargo, la exportación de $\mathrm{N}$ fue de $281 \mathrm{t}$ año ${ }^{-1}$. La carga de $\mathrm{N}$ por unidad de área de la microcuenca y de los suelos agrícolas fue de $25.3 \mathrm{~kg} \mathrm{ha}^{-1}$ año $^{-1}$, mientras que la carga de $\mathrm{N}$ que entra al sistema de Urías fue de 384 a $395 \mathrm{~kg}$ año ${ }^{-1}$ por hectárea de espejo de agua.

Las fuentes de $\mathrm{N}$ que llegan al sistema de Urías variaron temporalmente. En la época lluviosa se produce la entrada de lixiviados terrestres de la microcuenca del sistema de Urías y del lavado de suelos agrícolas, principalmente por los canales del HL y por el estero Infiernillo en el HLM, además de los aportes de efluentes acuícolas de dos granjas que operan en el HL (de agosto a diciembre y de abril a junio). Las aguas residuales y los efluentes del procesamiento de productos pesqueros descargan en la zona intermedia (HLM) y son fuentes relativamente constantes a lo largo del año.

La caracterización isotópica de las fuentes de $\mathrm{N}$ (tabla 1) varió desde señales bajas para los escurrimientos agrícolas $(2.1 \pm 0.70 \%$; media \pm desviación estándar) hasta muy elevadas para las aguas residuales tratadas $(16.1 \pm 0.30 \%$ ) y los efluentes del procesamiento de productos pesqueros (19.1 \pm $0.68 \%$ ). En promedio, la señal derivada de los lixiviados de la microcuenca del sistema de Urías varió poco (1.4-2.8\%), dependiendo de los terrenos que fueron lavados. $\mathrm{El} \mathrm{NO}_{3}{ }^{-}$de origen marino varió de $1.9 \%$ a $5.5 \%$ según la temporada de muestreo. El $\mathrm{N}$ descargado vía aguas subterráneas no fue considerado. Sin embargo, consideramos que la fuente principal de $\mathrm{N}$ al acuífero es el depósito atmosférico y, en menor proporción, los escurrimientos agrícolas que descargan en la 
Table 1. Nitrogen loads and isotopic composition of nitrogen sources discharging into the Urías lagoon system. The isotopic and fractionation values of the sources are based on the differences between the signals observed in the water column and those of the original sources.

Tabla 1. Cargas de nitrógeno y composición isotópica de las fuentes de nitrógeno que llegan al sistema lagunar de Urías. Se muestran los valores isotópicos de las fuentes y su fraccionación basada en las diferencias de las señales observadas en la columna de agua y las de las fuentes originales.

\begin{tabular}{|c|c|c|c|c|c|}
\hline N sources & $\begin{array}{l}\mathrm{N} \text { loading } \\
\left(\mathrm{t} \mathrm{yr}^{-1}, \%\right)\end{array}$ & \multicolumn{2}{|c|}{$\delta^{15} \mathrm{~N}^{-\mathrm{NH}_{4}}{ }^{+}(\%)$} & \multicolumn{2}{|c|}{$\delta^{15} \mathrm{~N}^{-\mathrm{NO}_{3}}{ }^{-}(\%)$} \\
\hline Aquaculture & $33-52,6.5$ & $8.00 \pm 1.00$ & $5.51 \pm 3.91$ & $6.71 \pm 4.89$ & $3.01 \pm 2.10$ \\
\hline Agriculture & $97.4,14$ & $4.00 \pm 1.00$ & $0.91 \pm 2.40$ & $2.10 \pm 0.70$ & $6.28 \pm 1.59$ \\
\hline Sewage & $195.2,27$ & $16.10 \pm 0.30$ & $3.59 \pm 4.91$ & $8.19 \pm 1.89$ & $1.57 \pm 3.09$ \\
\hline Seafood processing industry & $>74.6,10.5$ & $19.10 \pm 0.68$ & $1.42 \pm 0.79$ & $8.17 \pm 3.25$ & $2.10 \pm 1.03$ \\
\hline Atmospheric deposit & 203,29 & $11.80 \pm 4.30$ & ND & $-13.80 \pm 3.90$ & ND \\
\hline
\end{tabular}

ND, not determined.

values during the dry and rainy seasons, respectively; and DO on average ranged from $2.40 \pm 0.98$ to $10.2 \pm 0.98 \mathrm{mg} \mathrm{L}^{-1}$, with values as low and high as $<1$ and $16.7 \mathrm{mg} \mathrm{L}^{-1}$, respectively. Minimum values of DO $\left(0.77-2.0 \mathrm{mg} \mathrm{L}^{-1}\right)$ were mainly observed within the tidal channels in $\mathrm{LH}$ and $\mathrm{LMH}$ (e.g., Infiernillo and Confites estuaries) and at other sites in LMH. In these low DO zones, sediments display anoxic conditions $\left(\mathrm{H}_{2} \mathrm{~S}\right.$ formation and blackish color).

The levels of $\mathrm{NH}_{4}^{+}$ranged from $13.1 \pm 10.2 \mu \mathrm{g} \mathrm{L} \mathrm{L}^{-1}$ (December, $\mathrm{MH}$ ) to $245 \pm 172 \mu \mathrm{g} \mathrm{L}^{-1}$ (May, LMH) (table 3). Note that $\mathrm{NH}_{4}^{+}$concentrations $\geq 1180 \mu \mathrm{g} \mathrm{L}^{-1}$ were recorded at one site in $\mathrm{LMH}$, associated with industrial effluents. The concentrations of $\mathrm{NO}_{3}^{-}$plus $\mathrm{NO}_{2}^{-}$ranged from $6.18 \pm$ $1.56 \mu \mathrm{g} \mathrm{L}^{-1}$ (March, MH) to $204 \pm 80.1 \mu \mathrm{g} \mathrm{L}^{-1}$ (November, LMH). The TDN levels also varied widely, between $134 \pm$ $4.63 \mu \mathrm{g} \mathrm{L}^{-1}$ (February, MH) and $2836 \pm 1231 \mu \mathrm{g} \mathrm{L}^{-1}$ (May, LMH). A high percentage $(\sim 80 \%)$ of TDN corresponded to DON, which is related to diverse anthropogenic inputs of organic matter, in particular sewage and industrial effluents.

Similar to the $\mathrm{N}$ concentrations, the isotopic values for both chemical forms also showed high spatial and temporal variation: $\delta^{15} \mathrm{~N}_{-} \mathrm{NH}_{4}{ }^{+}$, from $13.0 \pm 2.8 \%$ to $20.1 \pm 1.8 \%$; $\delta^{15} \mathrm{~N}_{-} \mathrm{NO}_{3}^{-}$, from $0.85 \pm 0.06 \%$ to $13 \%$ (table 4 ). The lowest values for $\delta^{15} \mathrm{~N}-\mathrm{NH}_{4}{ }^{+}(13.0-14.4 \%)$ and $\delta^{15} \mathrm{~N}-\mathrm{NO}_{3}{ }^{-}$ (0.85-3.93\%) were recorded during the rainy season in $\mathrm{LH}$, whereas the highest were recorded in LMH throughout the year (17.4-20.1\%o) and in LH during the dry-cold season (8.3-13\%).

The differences between the $\delta^{15} \mathrm{~N}-\mathrm{NO}_{3}{ }^{-}$and $\delta^{15} \mathrm{~N}-\mathrm{NH}_{4}{ }^{+}$ values measured in the water column and in the original sources $(\gamma)$ (table 1) indicated enrichment. The mean differences were $1.6 \%$ to $6.3 \%$ (range of $0 \%$ o to $12 \%$ ) for $\mathrm{NO}_{3}{ }^{-}$and $\sim 1.0 \%$ o to $5.5 \%$ (range of $0 \%$ o to $10 \%$ ) for $\mathrm{NH}_{4}^{+}$. Considering that $\mathrm{NH}_{4}^{+}$is the predominant form of sewage and industrial effluents and given that there is no direct source of $\mathrm{NO}_{3}^{-}$in the area that receives such effluents sub-cuenca de Mazatlán y las aguas residuales de sistemas de letrinas en asentamientos suburbanos y rurales.

\section{Variables ambientales, formas químicas y composición isotópica del nitrógeno}

La variación espaciotemporal de la $\mathrm{T}, \mathrm{S}, \mathrm{pH}$ y $\mathrm{OD}$ en el sistema de Urías durante el periodo de estudio se resume en la tabla 2. La T varió de $22.2 \pm 1.5$ a $33.6 \pm 0.59{ }^{\circ} \mathrm{C}$. La S varió de $25.9 \pm 2.5$ a $39.8 \pm 2.8$. El pH promedió $7.81 \pm 0.26$, con mínimos en secas y máximos en lluvias. El OD varió en promedió de $2.40 \pm 0.98$ a $10.2 \pm 0.98 \mathrm{mg} \mathrm{L}^{-1}$, con valores tan bajos como $<1 \mathrm{mg} \mathrm{L}^{-1}$ a máximos de $16.7 \mathrm{mg} \mathrm{L}^{-1}$. Se observaron mínimos de OD (de 0.77 a $2.0 \mathrm{mg} \mathrm{L}^{-1}$ ) principalmente en el interior de los canales de marea del HL y HLM (e.g., esteros Infiernillo y Confites) y en otros sitios del HLM. En estas zonas de bajo OD, los sedimentos evidencian condiciones de anoxia (formación de $\mathrm{H}_{2} \mathrm{~S}$ y coloración negruzca).

El $\mathrm{NH}_{4}{ }^{+}$varió de $13.1 \pm 10.2 \mu \mathrm{g} \mathrm{L}^{-1}$ (diciembre, $\mathrm{HM}$ ) a $245 \pm 172 \mu \mathrm{g} \mathrm{L}^{-1}$ (mayo, HLM) (tabla 3). Cabe destacar que en uno de los sitios del HLM se registraron concentraciones de $\mathrm{NH}_{4}^{+} \geq 1180 \mu \mathrm{g} \mathrm{L}^{-1}$, asociadas a la descarga de efluentes del procesamiento de productos pesqueros. La suma de $\mathrm{NO}_{3}{ }^{-}$ con $\mathrm{NO}_{2}^{-}$varió de $6.18 \pm 1.56 \mu \mathrm{g} \mathrm{L}^{-1}$ (marzo, HM) a $204 \pm$ $80.1 \mu \mathrm{g} \mathrm{L}^{-1}$ (noviembre, HLM). El NDT también presentó una amplia variabilidad, de $134 \pm 4.63 \mu \mathrm{g} \mathrm{L}^{-1}$ (febrero, HM) a $2836 \pm 1231 \mu \mathrm{g} \mathrm{L}^{-1}$ (mayo, HLM). Un alto porcentaje $(\sim 80 \%)$ del NDT correspondió a NOD, lo cual está relacionado con los aportes de materia orgánica de diversas actividades, en particular las aguas residuales y el procesamiento de productos pesqueros.

Al igual que ocurrió con las concentraciones de $\mathrm{N}$, se observó una alta variación espacial y temporal en los valores isotópicos para ambas formas químicas: $\delta^{15} \mathrm{~N}-\mathrm{NH}_{4}{ }^{+}$varió de $13.0 \pm 2.8 \%$ a $20.1 \pm 1.8 \%$ y $\delta^{15} \mathrm{~N}-\mathrm{NO}_{3}{ }^{-}$varió de $0.85 \pm$ $0.06 \%$ a $13 \%$ o (tabla 4 ). Los valores más bajos del $\delta^{15} \mathrm{~N}-\mathrm{NH}_{4}{ }^{+}$ 


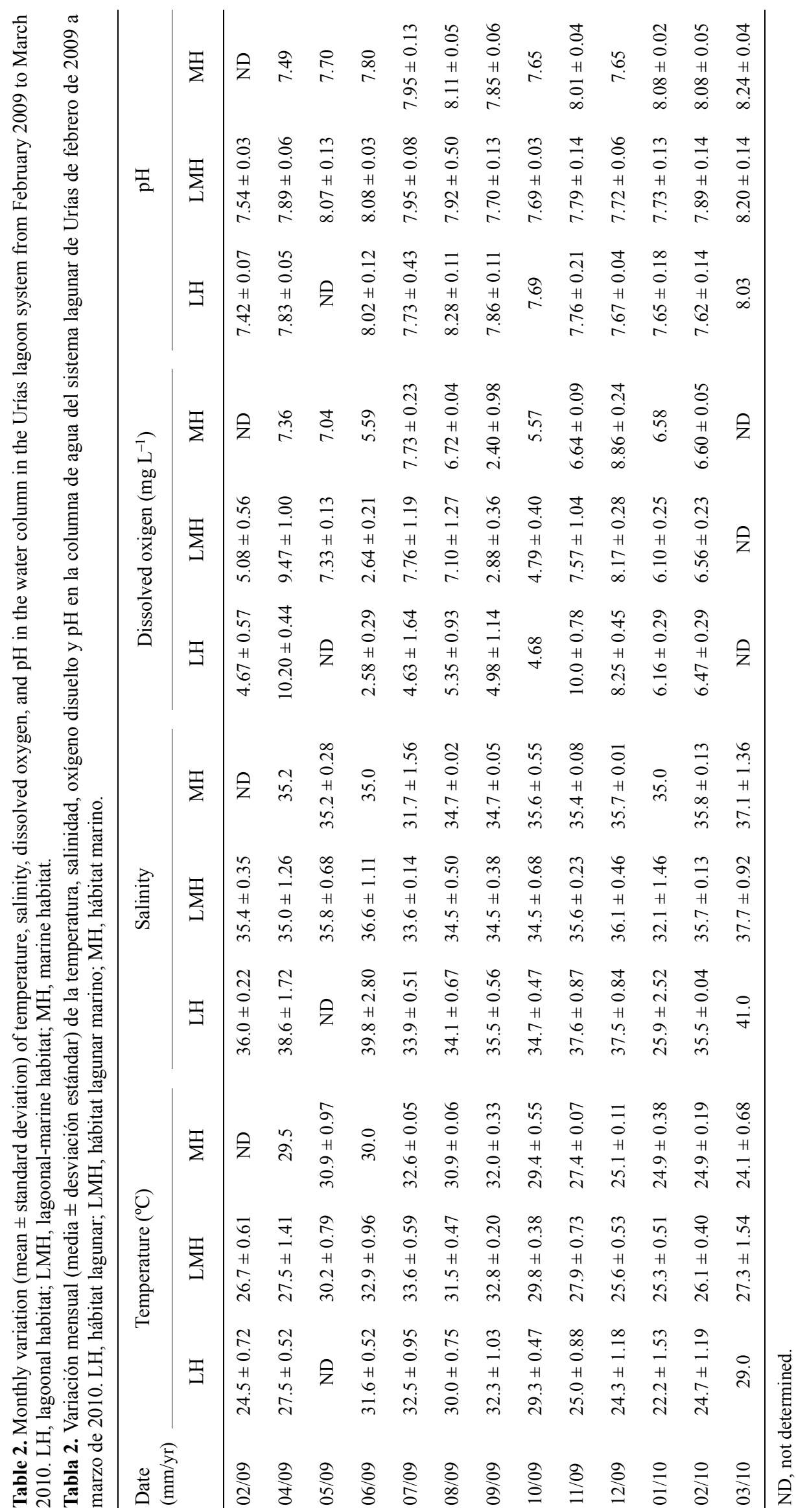




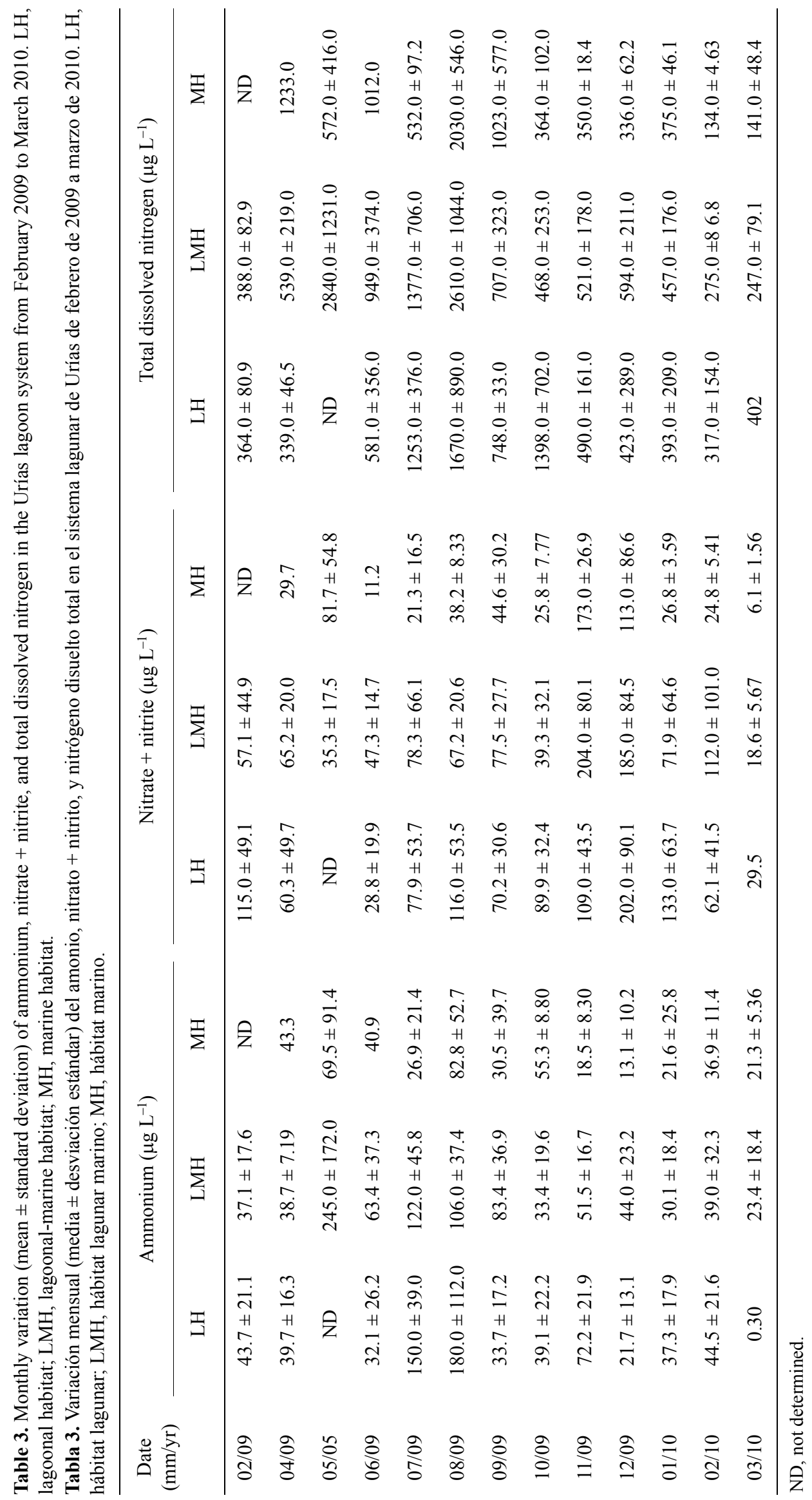


Ciencias Marinas, Vol. 39, No. 4, 2013

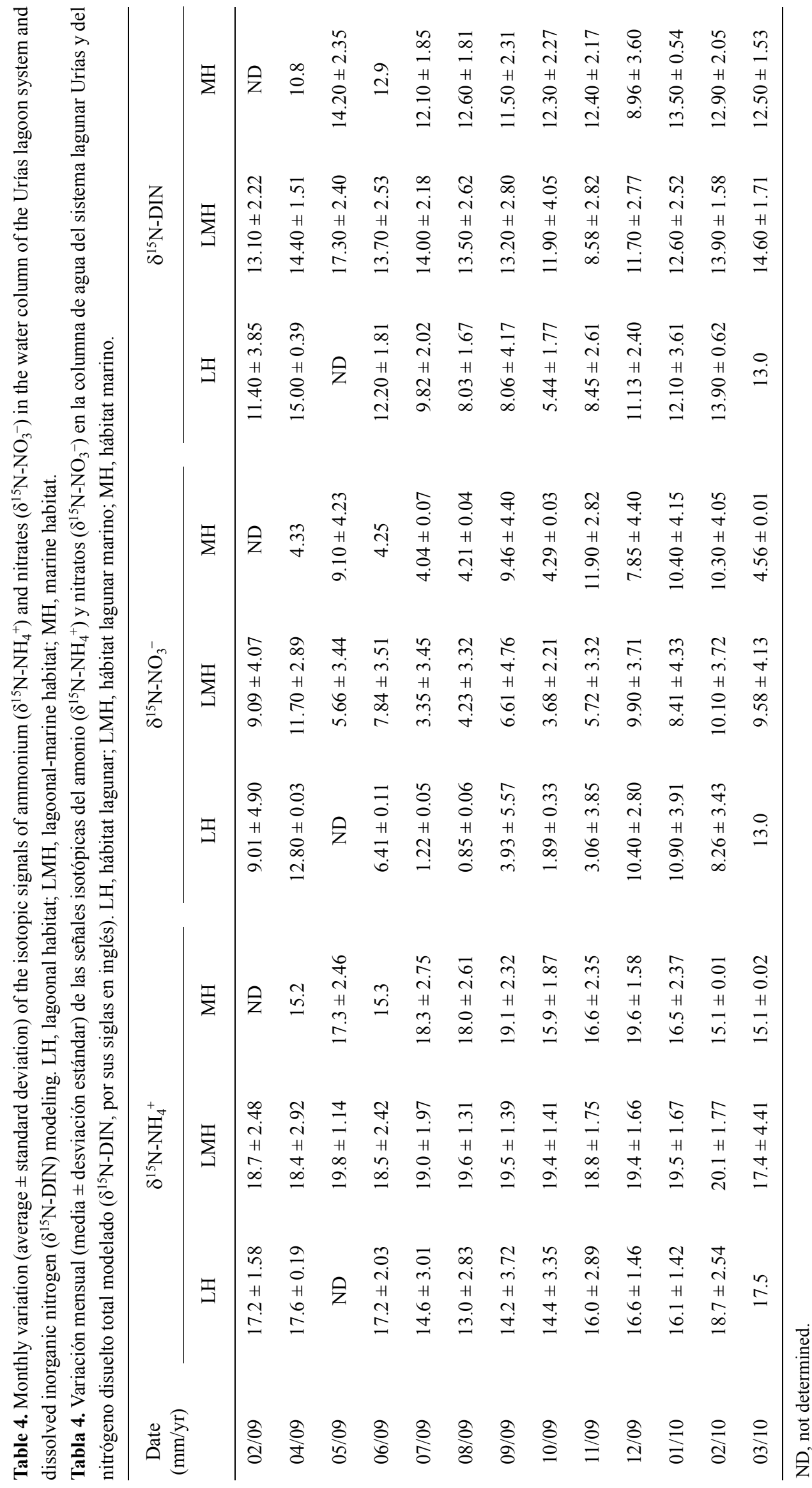


( $\mathrm{LMH}$ ), the presence of $\mathrm{NO}_{3}{ }^{-}$in these waters is due to nitrification. The signals observed for $\mathrm{NO}_{3}^{-}$averaged $\sim 8.2 \%$ (product), whereas those for $\mathrm{NH}_{4}{ }^{+}$ranged from $16.1 \%$ o to $19.1 \%$ (reactive).

\section{Modelling $\delta^{15} \mathbf{N}$-DIN and $\delta^{15} \mathrm{~N}$-macroalgae}

Two mixing models were used to estimate the isotopic signals of $\mathrm{N}$ available in the water column $\left(\delta^{15} \mathrm{~N}-\mathrm{DIN}\right)$ and they were compared to the $\mathrm{NH}_{4}{ }^{+}$and $\mathrm{NO}_{3}{ }^{-}$signals observed $\left(\delta^{15} \mathrm{~N}_{\mathrm{obs}}\right)$ using diffusion methods. According to the results of the linear regression analysis, a better fit was obtained with the coupled model than with the simple model for both $\mathrm{NH}_{4}{ }^{+}$ (coupled model: $\delta^{15} \mathrm{~N}-\mathrm{NH}_{4}{ }^{+}=1.04\left[\delta^{15} \mathrm{~N}-\mathrm{NH}_{4}{ }^{+}\right.$obs$]-0.64, R^{2}=$ 0.78; simple model: $\delta^{15} \mathrm{~N}^{+} \mathrm{NH}_{4}{ }^{+}=0.93\left[\delta^{15} \mathrm{~N}^{+} \mathrm{NH}_{4}{ }^{+}{ }_{\mathrm{obs}}\right]-0.89$,

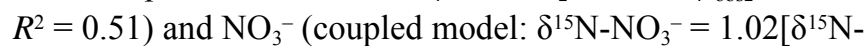
$\mathrm{NO}_{3}{ }^{-}$obs $]-0.07, R^{2}=0.87$; simple model: $\delta^{15} \mathrm{~N}^{-} \mathrm{NO}_{3}{ }^{-}=$ $0.88\left[\delta^{15} \mathrm{~N}^{-\mathrm{NO}_{3}{ }^{-} \text {obs }}\right]-1.40, R^{2}=0.69$ ). Both forms showed a lower slope and more negative intercept in the simple model, which indicates lower signals relative to the coupled model.

To validate the premise that macroalgae can be used as biomonitors of $\mathrm{N}$ pollution, we established the relation $\left(13.0-14.4 \%\right.$ ) y del $\delta^{15} \mathrm{~N}-\mathrm{NO}_{3}^{-}(0.85-3.93 \%)$ se registraron durante la época de lluvias en el HL, y los más altos se registraron en el HLM todo el año (17.4-20.1\%) y en el HL en la época seca-fría (8.3-13\%o).

Las diferencias entre los valores de $\delta^{15} \mathrm{~N}-\mathrm{NO}_{3}{ }^{-}$y $\delta^{15} \mathrm{~N}-\mathrm{NH}_{4}{ }^{+}$medidos en la columna de agua y en las fuentes originales $(\gamma)$ (tabla 1) mostraron un enriquecimiento en la señales. Las diferencias promedio fueron de $1.6 \%$ a $6.3 \%$ (rango de $0 \%$ a $12 \%$ ) para $\mathrm{NO}_{3}^{-}$y de $\sim 1.0 \%$ a $5.5 \%$ (rango de $0 \%$ a $10 \%$ ) para $\mathrm{NH}_{4}^{+}$. Considerando que el $\mathrm{NH}_{4}{ }^{+}$es la forma predominante en los efluentes del procesamiento de productos pesqueros y las aguas residuales y dado que no hay fuente directa de $\mathrm{NO}_{3}^{-}$en el área que recibe tales efluentes (HLM), la presencia de $\mathrm{NO}_{3}{ }^{-}$en estas aguas es producto de la nitrificación. Las señales observadas para el $\mathrm{NO}_{3}{ }^{-}$promediaron en $\sim 8.2 \%$ (producto), mientras que las de $\mathrm{NH}_{4}{ }^{+}$variaron de $16.1 \%$ a $19.1 \%$ (reactivo).

\section{Modelación del $\delta^{15} \mathbf{N}-\mathrm{NID}$ y $\delta^{15} \mathbf{N}$-macroalgas}

Con el modelo simple y el modelo acoplado se estimaron las señales isotópicas del $\mathrm{N}$ disponible en el agua $\left(\delta^{15} \mathrm{~N}-\mathrm{NID}\right)$,

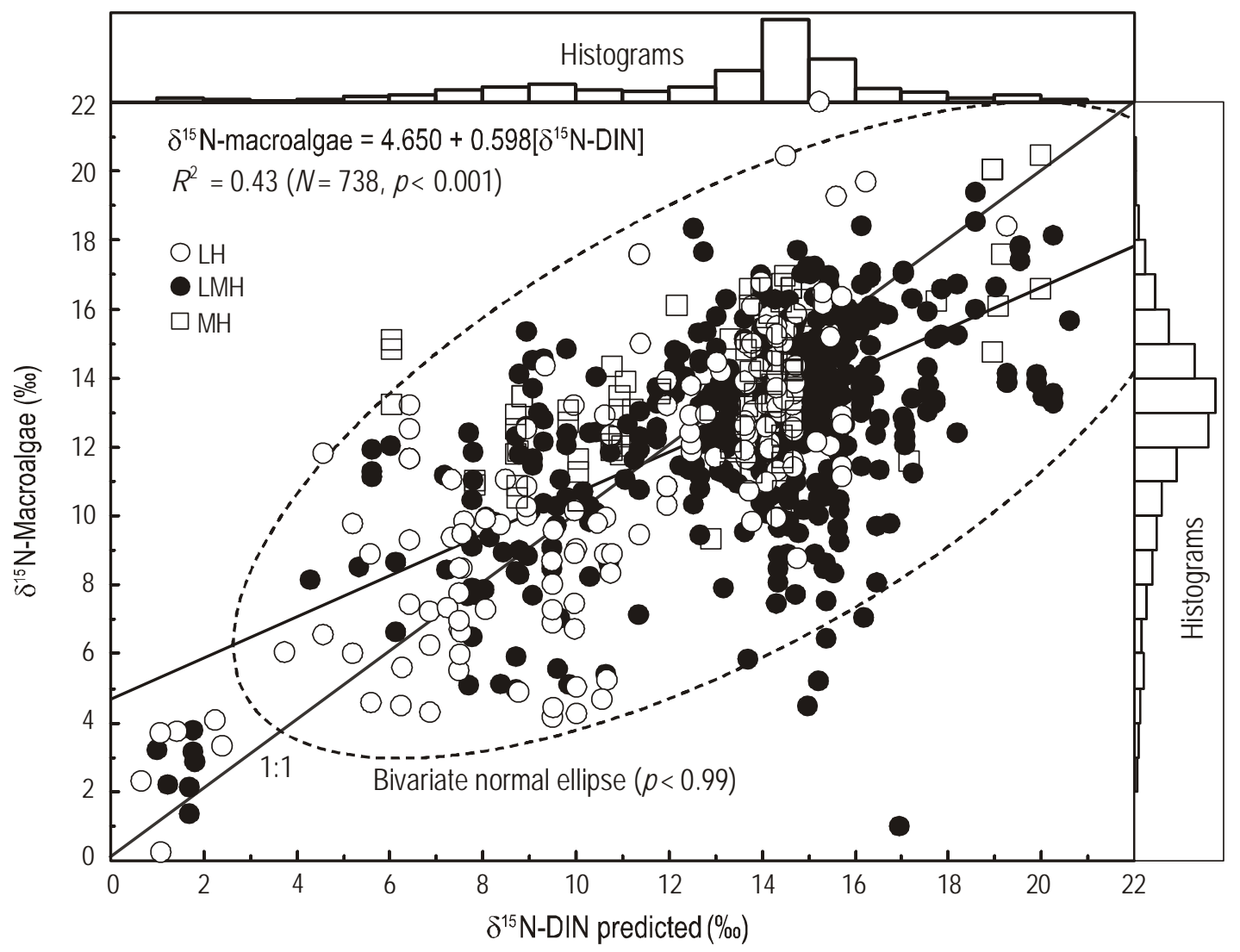

Figure 2. Results of the linear regression analysis between $\delta^{15} \mathrm{~N}$-DIN available in the water column and $\delta^{15} \mathrm{~N}$-macroalgae from the Urías lagoon system. $\mathrm{LH}$, lagoonal habitat; $\mathrm{LMH}$, lagoonal-marine habitat; $\mathrm{MH}$, marine habitat.

Figura 2. Resultados del análisis de regresión lineal entre el $\delta^{15} \mathrm{~N}-\mathrm{NID}$ (DIN, por sus siglas en inglés) disponible en el agua y el $\delta^{15} \mathrm{~N}$ en las macroalgas recolectadas en el sistema lagunar de Urías. LH, hábitat lagunar; LMH, hábitat lagunar-marino; MH, hábitat marino. 
between $\delta^{15} \mathrm{~N}$-DIN and the isotopic signals of the 738 samples of macroalgae collected (fig. 2). The analysis revealed that all specimens had a significant $R^{2}(0.43 ; n=738 ; P<$ 0.001 ); however, there was high data dispersion related to the high isotopic variability in algae and DIN, as well as a lower than expected $R^{2}$.

\section{Relative contribution of nitrogen sources to $\delta^{15} \mathrm{~N}-\mathrm{DIN}$ and $\delta^{15} \mathbf{N}$-macroalgae}

The sewage effluents contributed $50 \%$ (45-56\%) of $\mathrm{N}$ in the water column, atmospheric deposition contributed $24 \%$ (22-28\%), industrial effluents $21 \%(12-29 \%)$, aquaculture $3 \%(0-12 \%)$, and agriculture $1 \%(0-7 \%)$, and $1 \%$ was of oceanic origin ( $0-3 \%)$ (fig. 3$)$. The relative contributions in all the macroalgal specimens reflected that $41 \%(27-51 \%)$ of $\mathrm{N}$ was derived from sewage, $33 \%(2-45 \%)$ from atmospheric deposition, $10 \%(0-21 \%)$ from aquaculture, $8 \%(0-25 \%)$ from industrial effluents, and 4\% (0-18\%) from agriculture, and $4 \%(0-22 \%)$ was of oceanic origin.

\section{DISCUSSION}

The method of $\delta^{15} \mathrm{~N}$ in macroalgae used to determine the relative contributions of $\mathrm{N}$ sources to the Urías lagoon system is useful to assess the effect of different human activities on the ecosystem and thus be able to establish preventive measures. This is the first step in any management program aiming to restore coastal zones; however, in the case of the

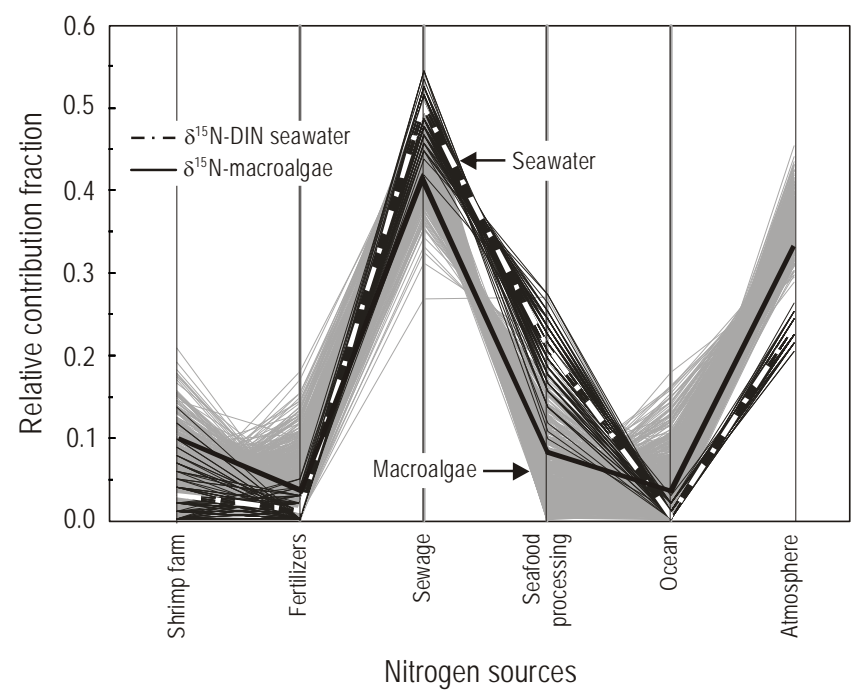

Figure 3. Relative contribution of nitrogen sources to $\delta^{15} \mathrm{~N}-\mathrm{DIN}$ available in the water column and to $\delta^{15} \mathrm{~N}$-macroalgae from the Urías lagoon system.

Figura 3. Contribución relativa de las fuentes de nitrógeno al $\delta^{15} \mathrm{~N}-\mathrm{NID}$ (DIN, por sus siglas en inglés) disponible en la columna de agua y al $\delta^{15} \mathrm{~N}$ de las macroalgas recolectadas en el sistema lagunar de Urías. y éstas fueron comparadas con las señales de $\mathrm{NH}_{4}^{+}$y $\mathrm{NO}_{3}{ }^{-}$ observadas $\left(\delta^{15} \mathrm{~N}_{\mathrm{obs}}\right)$ utilizando las técnicas de difusión. De acuerdo con los resultados del análisis de regresión lineal, se observó que el modelo acoplado tuvo un mejor ajuste que el modelo simple, tanto para $\mathrm{NH}_{4}{ }^{+}$(modelo acoplado: $\delta^{15} \mathrm{~N}$ -

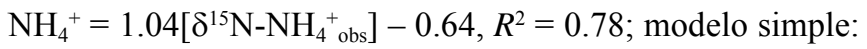

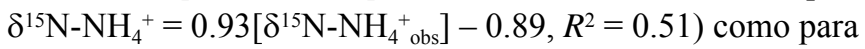
$\mathrm{NO}_{3}^{-}$(modelo acoplado: $\delta^{15} \mathrm{~N}_{-} \mathrm{NO}_{3}{ }^{-}=1.02\left[\delta^{15} \mathrm{~N}^{-\mathrm{NO}_{3}}{ }^{-}\right.$obs $]-$ $0.07, R^{2}=0.87$; modelo simple: $\delta^{15} \mathrm{~N}^{-\mathrm{NO}_{3}}{ }^{-}=0.88\left[\delta^{15} \mathrm{~N}-\right.$ $\mathrm{NO}_{3}{ }^{-}$obs $\left.]-1.40, R^{2}=0.69\right)$. Ambas formas químicas presentaron una pendiente más baja y un intercepto más negativo en el modelo simple, lo cual indica señales más bajas respecto al modelo acoplado.

Para validar la premisa del uso de las macroalgas como biomonitores de contaminación por $\mathrm{N}$, se estableció la relación entre el $\delta^{15} \mathrm{~N}-\mathrm{NID}$ modelado en la columna de agua con las señales isotópicas en las 738 muestras de macroalgas recolectadas (fig. 2). El análisis reveló que los especímenes en conjunto tuvieron un valor significativo de $R^{2}(0.43 ; n=$ 738; $P<0.001)$. Sin embargo, se observó una alta dispersión de los datos relacionada con la alta variabilidad isotópica en las algas y en el NID, además de un $R^{2}$ más bajo del esperado.

\section{Contribución relativa de las fuentes de nirtógeno al $\delta^{15} \mathbf{N}-\mathbf{N I D}$ y al $\delta^{15} \mathbf{N}$-macroalgas}

Las aguas residuales aportaron el 50\% (45-56\%) del $\mathrm{N}$ reflejado en el agua, el depósito atmosférico el $24 \%$ (22-28\%), los efluentes del procesamiento de productos pesqueros el $21 \%(12-29 \%)$, los efluentes acuícolas el $3 \%$ (0-12\%), los escurrimientos agrícolas el $1 \%(0-7 \%)$ y la fuente marina el 1\% (0-3\%) (fig. 3). Las contribuciones relativas en todos los especímenes de macroalgas reflejaron que el $41 \%(27-51 \%)$ del $\mathrm{N}$ se derivó de las aguas residuales, el $33 \%(2-45 \%)$ del depósito atmosférico, el 10\% (0-21\%) de efluentes acuícolas, el $8 \%(0-25 \%)$ de los efluentes del procesamiento de productos pesqueros y el $4 \%(0-18 \%)$ de escurrimientos agrícolas, y el $4 \%(0-22 \%)$ de $\mathrm{N}$ fue de origen oceánico.

\section{DISCUSIÓN}

La aplicación de la técnica del $\delta^{15} \mathrm{~N}$ en macroalgas para determinar las contribuciones relativas de las fuentes de $\mathrm{N}$ que entran al sistema de Urías es útil para evaluar el impacto que están ocasionando las diferentes actividades humanas al ecosistema y poder tomar medidas en consecuencia. Este es un primer paso en cualquier plan de manejo para restaurar las zonas costeras prioritarias del país; sin embargo, siendo el sistema de Urías un ecosistema tan estresado y complejo, con múltiples fuentes de $\mathrm{N}$, condiciones ambientales cambiantes en el tiempo y espacio, y una amplia diversidad de especies de macroalgas, se obtiene como resultado una 
Urías system, which is such a stressed and complex ecosystem, with multiple $\mathrm{N}$ sources, a diversity of macroalgal species, and changing environmental conditions in space and time, the result is high isotopic variability that tends to obscure any distinction of the $\mathrm{N}$ sources in macroalgae.

There are three explanations for this "lack of fit" and high variability of the data: (a) the multiple $\mathrm{N}$ sources that enter the system and vary spatially and temporarily, with different chemical forms of $\mathrm{N}$ and a wide range of isotopic signals; (b) the complex biogeochemical processes related to the $\mathrm{N}$ cycle alter its chemical form and isotopic composition; and (c) the high diversity of macroalgal species collected (45), with an additional effect due to fractionation by assimilation. This results in high spatial and temporal variation of the concentration and isotopic signal of $\mathrm{N}$ in the water column and, consequently, the macroalgae.

Most of the biogeochemical processes such as ammonium volatilization, nitrification, denitrification, ammonification, and $\mathrm{N}$ assimilation alter the concentration, chemical form, and/or isotopic compostion of $\mathrm{N}$ in the water column (Valiela et al. 1997, Kendall and Cadwell 1998, McClelland and Valiela 1998, Ricaurte-Villota et al. 2013). Based on the spatial and temporal variations of $\mathrm{T}, \mathrm{S}, \mathrm{pH}$, and $\mathrm{DO}$, and the chemical forms of $\mathrm{N}$ in the system, we suggest that the processes that have most impact are ammonium volatilization and denitrification. The relatively high values of $\mathrm{pH}, \mathrm{T}$, and $\mathrm{S}$ at the LH and LMH sites, as well as the high rates of organic matter decomposition and consequent production of $\mathrm{NH}_{4}^{+}$, favor the conversion of $\mathrm{NH}_{4}^{+}$to $\mathrm{NH}_{3}$ and subsequent volatilization in the water column. The low DO levels observed in $\mathrm{LH}$ and at different LMH sites, together with the high concentrations of $\mathrm{NO}_{3}{ }^{-}$and accumulation of organic matter (1.2-4.1\% of organic carbon) (Soto-Jiménez and Páez-Osuna 2001), high temperatures $\left(\mathrm{T}>20{ }^{\circ} \mathrm{C}\right)$, optimum $\mathrm{pH}$ (7.4-8.54), and long residence times, accelerate the denitrifi-

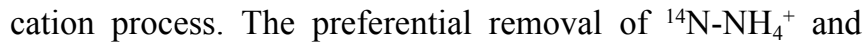
${ }^{14} \mathrm{~N}-\mathrm{N}_{2}$ results in an enrichment of residual $\mathrm{NH}_{4}{ }^{+}$and $\mathrm{NO}_{3}{ }^{-}$ relative to their original signal.

Simultaneous nitrification-denitrification is controversial because the biogeochemical processes of the $\mathrm{N}$ cycle that occur in the water column and sediments are not always coupled (Valiela et al. 1997, Soto-Jiménez et al. 2003b), particularly in highly eutrophized environments such as the Urías system. Although little research has been done on these processes in subtropical coastal environments, we maintain that coupling occurs in the Urías system when conditions are stable (e.g., dry-cold season), as has been observed in other coastal ecosystems (Dollhopf et al. 2005). Coupling occurs mainly in areas where mangroves grow, where the oxygen released from the roots promotes nitrification close to the anoxic sediment zone, in turn stimulating denitrification (Ottosen et al. 1999). Coupling, however, does not occur during the rainy season, when most of the $\mathrm{N}$ inputs are in the form of $\mathrm{NO}_{3}^{-}$and organic matter. elevada variabilidad isotópica que tiende a obscurecer cualquier distinción de las fuentes de $\mathrm{N}$ en las macroalgas.

La "falta de ajuste" y la alta variabilidad de los datos observados pueden ser explicadas por (a) las múltiples fuentes de $\mathrm{N}$ que entran al sistema y que varían espacial y temporalmente, con diferentes formas químicas de $\mathrm{N}$ y un rango de señales isotópicas muy amplio; (b) los procesos biogeoquímicos complejos relacionados con el ciclo de $\mathrm{N}$ que alteran su forma química y composición isotópica; y (c) la gran diversidad de especies de macroalgas recolectadas (45), con un efecto adicional debido a la fraccionación por asimilación. Todo lo anterior resulta en una amplia variabilidad espacial y temporal en la concentración y señal isotópica del $\mathrm{N}$ en la columna de agua y, como consecuencia, en la macroalga.

La mayoría de los procesos biogeoquímicos como la nitrificación, desnitrificación, amonificación, volatilización de amonio y asimilación de $\mathrm{N}$ alteran la concentración, forma química y/o la composición isotópica del $\mathrm{N}$ en la columna de agua (Valiela et al. 1997, Kendall y Cadwell 1998, McClelland y Valiela 1998, Ricaurte-Villota et al. 2013). Con base en las variaciones espaciotemporales de T, $\mathrm{S}, \mathrm{pH}$ y OD, y las formas químicas del $\mathrm{N}$ en el sistema, consideramos que los procesos que tienen mayor impacto son la volatilización de amonio y la desnitrificación. Los valores relativamente altos de $\mathrm{pH}$, T y $\mathrm{S}$ en sitios del HL y HLM, así como las altas tasas de descomposición de materia orgánica con su consecuente producción de $\mathrm{NH}_{4}{ }^{+}$, favorecen la conversión de $\mathrm{NH}_{4}{ }^{+}$ a $\mathrm{NH}_{3}$ y su posterior volatilización en la columna de agua. Los bajos niveles de OD observados en el HL y en distintos sitios del HLM, junto con las altas concentraciones de $\mathrm{NO}_{3}^{-} \mathrm{y}$ acumulación de materia orgánica $(1.2-4.1 \%$ de carbono orgánico) (Soto-Jiménez y Páez-Osuna 2001), las altas temperaturas $\left(\mathrm{T}>20^{\circ} \mathrm{C}\right)$, el $\mathrm{pH}$ en el intervalo óptimo (7.4-8.54) y los largos tiempos de residencia, aceleran la desnitrificación al máximo. La remoción preferencial del ${ }^{14} \mathrm{~N}^{-\mathrm{NH}_{4}}{ }^{+} \mathrm{y}$ ${ }^{14} \mathrm{~N}-\mathrm{N}_{2}$ resulta en un enriquecimiento del $\mathrm{NH}_{4}^{+}$y $\mathrm{NO}_{3}{ }^{-}$residual con respecto a su señal original.

La nitrificación-desnitrificación es controversial dado que los procesos biogeoquímicos del ciclo del $\mathrm{N}$ que ocurren en la columna de agua y en los sedimentos no siempre se encuentran acoplados (Valiela et al. 1997, Soto-Jiménez et al. 2003b), en particular en ambientes altamente eutrofizados como el sistema de Urías. Aunque el estudio de estos procesos en ambientes costeros subtropicales es muy limitado, nosotros sostenemos la hipótesis del acoplamiento en el sistema de Urías en épocas con condiciones estables (e.g., en la época seca-fría), como ha sido observado en otros ecosistemas costeros (Dollhopf et al. 2005). Dicho acoplamiento ocurre mayormente en las áreas con manglar, donde el oxígeno liberado desde las raíces fomenta la nitrificación cerca de la zona anóxica de los sedimentos, estimulando a su vez la desnitrificación (Ottosen et al. 1999). Sin embargo, el acople se rompe en la época lluviosa, cuando se da el mayor aporte de $\mathrm{N}$ en la forma de $\mathrm{NO}_{3}^{-}$y de materia orgánica. 
In addition to the different $\mathrm{N}$ sources and biogeochemical processes, the diversity and condition (e.g., juvenile, adult) of the macroalgal species also contribute to high isotopic variability. Few studies have measured fractionation factors during $\mathrm{N}$ uptake by macroalgae. Swart et al (2008) reported values of $2-4 \%$ for $\mathrm{NH}_{4}{ }^{+}$or $\mathrm{NO}_{3}{ }^{-}$uptake, and Kaldy (2011) obtained values of $3 \%$ for $\mathrm{NH}_{4}{ }^{+}$uptake and of $0 \%$ for $\mathrm{NO}_{3}$ uptake.

In general, the macroalgal $\delta^{15} \mathrm{~N}$ values obtained in this study fall within the range of values reported for other sites in the world affected by the same sources (Deutsch and Voss 2006, Dailer et al. 2010, Kaldy 2011). In Mexico, few similar studies have been conducted. Atmospheric deposition, wastewater discharges, agriculture, aquaculture, and livestock rearing were found to be the main sources of anthropogenic $\mathrm{N}$ in three coastal ecosystems of Sinaloa (Soto-Jiménez et al. 2003b, Piñón-Gimate et al. 2009). Untreated sewage pollutes the coastal zone of the Yucatán Península (Carruthers et al. 2005) and the Mexican Caribbean (Mutchler et al. 2007). In the Urías system, atmospheric deposit, sewage and industrial effluents are the most apparent sources in the water column and macroalgae and, therefore, have a greater impact on the system. Aquaculture and agricultural activities and oceanic $\mathrm{N}$ are less important.

In summary, macroalgal $\delta^{15} \mathrm{~N}$ is widely used to determine $\mathrm{N}$ sources and evaluate $\mathrm{N}$ pollution in coastal ecosystems; however, the different sources of variability observed in this study hampered the precise resolution of the mixing models used to estimate the $\mathrm{N}$ sources. It is necessary to use models that integrate factors which alter the chemical forms and isotopic signals of $\mathrm{N}$ (Moore and Semmens 2008) rather than the simple physical mixing models that do not consider fractionation (Phillips and Gregg 2003). Our coupled model allowed a better prediction of the available $\mathrm{N}$ isotopic signals relative to those observed in the water, and in turn the predicted $\delta^{15} \mathrm{~N}$ values showed a close association with those measured in the macroalgae. Biogeochemical processes such as volatilization and denitrification and even macroalgal uptake that increase the signal by several parts per thousand are among the most important factors to consider.

By applying physical mixing models and adding the effects of the biogeochemical processes associated with the $\mathrm{N}$ cycle, it was possible to largely explain the variability of $\delta^{15} \mathrm{~N}$-DIN in water and, therefore, in macroalgae. Though macroalgae are excellent biomonitors of $\mathrm{N}$ in the ecosystem, their signals are a reflection of the $\mathrm{N}$ available in water and not necessarily of the sources that contribute it. Macroalgae integrate all the variability and reflect the isotopic signal resulting from all the processes. On the other hand, macroalgae (and their condition) can modify the $\mathrm{N}$ signal. So, for macroalgal $\delta^{15} \mathrm{~N}$ analysis to be a reliable tool for the evaluation of the contribution of each source to the ecosystem, it is necessary to consider all the sources of variation. Otherwise, erroneous conclusions may be reached.
Además de las múltiples fuentes de $\mathrm{N}$ y los procesos biogeoquímicos, la alta diversidad de especies de macroalgas y su condición (e.g., juvenil, adulta) también contribuyen a la elevada variabilidad isotópica. Pocos trabajos han medido los factores de fraccionación durante la asimilación de $\mathrm{N}$ por las macroalgas. Swart et al (2008) registaron valores de 2-4\% para la asimilación de $\mathrm{NH}_{4}{ }^{+}$o $\mathrm{NO}_{3}{ }^{-}$, y Kaldy (2011) registró valores de 3\%o para la asimilación de $\mathrm{NH}_{4}{ }^{+}$y $0 \%$ para $\mathrm{NO}_{3}{ }^{-}$.

En general, los valores $\delta^{15} \mathrm{~N}$ de las macroalgas registrados en este estudio se ubicaron en el rango de los valores $\delta^{15} \mathrm{~N}$ registrados para otros sitios del mundo impactados con las mismas fuentes (Deutsch y Voss 2006, Dailer et al. 2010, Kaldy 2011). En Mexico, los estudios de este tipo realizados en ecosistemas costeros son escasos, pero tales trabajos han revelado que el depósito atmosférico, las aguas residuales, los escurrimientos agrícolas, los efluentes acuícolas y los deshechos de engorda de animales fueron las principales fuentes de $\mathrm{N}$ antropogénico en tres ecosistemas costeros de Sinaloa (Soto-Jiménez et al. 2003b, Piñón-Gimate et al. 2009). Las aguas residuales sin tratar contaminan la zona costera de la península de Yucatán (Carruthers et al. 2005) y del Caribe mexicano (Mutchler et al. 2007). En el sistema de Urías, las aguas residuales, los efluentes del procesamiento de productos pesqueros y el depósito atmosférico son las fuentes que mejor se reflejan en la columna de agua y en las macroalgas $\mathrm{y}$, por tanto, las de mayor impacto al sistema. $\mathrm{La}$ actividad acuícola y agrícola y el $\mathrm{N}$ marino son menos importantes.

En resumen, el análisis del $\delta^{15} \mathrm{~N}$ en macroalgas para determinar las fuentes de $\mathrm{N}$ y evaluar la contaminación de $\mathrm{N}$ en los ecosistemas costeros es una herramienta muy utilizada a nivel mundial; sin embargo, las diferentes fuentes de variabilidad observadas en este estudio dificultan la resolución precisa de los modelos de mezcla para la estimación de las fuentes de aporte. Para esto, es necesario utilizar modelos que integren los factores que alteran las formas químicas y señales isotópicas del N (Moore y Semmens 2008) más allá de los simples modelos de intercambio físico que no consideran la fraccionación (Phillips y Gregg 2003). En este estudio, el modelo acoplado permitió una mejor predicción de las señales isotópicas del $\mathrm{N}$ disponible respecto a las observadas en el agua, y los valores de $\delta^{15} \mathrm{~N}$ predichos a su vez mostraron una alta asociación con aquellos medidos en las macroalgas. Los procesos biogeoquímicos tales como la volatilización y desnitrificación y la propia asimilación de la macroalga que incrementan la señal en varias partes por mil están entre los factores más importantes a considerar.

Mediante la aplicación de modelos de mezcla de intercambio físico y la adición de los efectos de los procesos biogeoquímicos asociados al ciclo del $\mathrm{N}$, fue posible explicar gran parte de la variabilidad del $\delta^{15} \mathrm{~N}-\mathrm{NID}$ en el agua y, por ende, en las macroalgas. Si bien, las macroalgas actúan como excelentes biomonitores del $\mathrm{N}$ en el ecosistema, sus señales son un reflejo del $\mathrm{N}$ disponible en el agua y no necesariamente de las fuentes que lo aportaron. Las macroalgas 


\section{ACKNOWLEDGMENTS}

This study was funded by the project UNAM-PAPIIT IN206409. We thank Humberto Bojórquez-Leyva, Arcelia Cruz-López, and Roberto Velázquez-Ochoa for help in the field and laboratory, and Yovani Montano-Ley and Victoria Montes-Montes for revising the manuscript. The valuable comments and suggestions of two anonymous reviewers are appreciated.

English translation by Christine Harris.

\section{REFERENCES}

Carruthers TJB, van Tussenbroek BI, Dennison WC. 2005. Influence of submarine springs and wastewater on nutrient dynamics of Caribbean seagrass meadows. Estuar. Coast. Shelf Sci. 64: 191-199 http://dx.doi.org/10.1016/j.ecss.2005.01.015

Cohen RA, Fong P. 2005. Experimental evidence supports the use of $\delta^{15} \mathrm{~N}$ content of the opportunistic green macroalgae Enteromorpha intestinalis (Chlorophyta) to determine nitrogen sources to estuaries. J. Phycol. 41: 287-293. http://dx.doi.org/10.1111/j.1529-8817.2005.04022.x

Dailer ML, Knox RS, Smith JE, Napier M, Smith CM. 2010. Using $\delta^{15} \mathrm{~N}$ values in algal tissue to map locations and potential sources of anthropogenic nutrient inputs on the island of Maui, Hawaii, USA. Mar. Pollut. Bull. 60: 655-671. http://dx.doi.org/10.1016/j.marpolbul.2009.12.021

Deutsch B, Voss M. 2006. Anthropogenic nitrogen input traced by means of $\delta^{15} \mathrm{~N}$ values in macroalgae: Results from in-situ incubation experiments. Sci. Total Environ. 366: 799-808. http://dx.doi.org/10.1016/j.scitotenv.2005.10.013

Dollhopf SL, Hyun JH, Smith AC, Adams HJ, O'Brien S, Kostka JE. 2005. Quantification of ammonia-oxidizing bacteria and factors controlling nitrification in salt marsh sediments. Appl. Environ. Microbiol. 71: 240-246. http://dx.doi.org/10.1128/AEM.71.1.240-246.2005

Grasshoff K, Ehrhardt M, Kremling K. 1983. Methods of Seawater Analysis. 2nd. ed. Verlag Chemie, Weinheim, 419 pp.

Heinen M. 2006. Application of a widely used denitrification model to Dutch data sets. Geoderma 13: 464-473. http://dx.doi.org/10.1016/j.geoderma.2005.08.011

Holmes RM, McClelland JW, Sigman DM, Fry B, Petersen BJ. 1998. Measuring ${ }^{15} \mathrm{~N}_{-} \mathrm{NH}_{4}{ }^{+}$in marine, estuarine and fresh waters: An adaptation of the ammonia diffusion method for samples with low ammonium concentrations. Mar. Chem. 60: 235-243. http://dx.doi.org/10.1016/S0304-4203(97)00099-6

Kaldy J. 2011. Using a macroalgal $\delta^{15} \mathrm{~N}$ bioassay to detect cruise ship wastewater effluent inputs. Mar. Pollut. Bull. 62: 1762-1771.

Kendall C. 1998. Tracing nitrogen sources and cycling in catchments. In: Kendall C, McDonnell JJ (eds.), Isotope Tracers in Catchment Hydrology. Elsevier, Amsterdam, pp. 519-576.

Kendall C, Caldwell EA. 1998. Fundamentals of isotope geochemistry. In: Kendall C, McDonnell JJ (eds.), Isotope Tracers in Catchment Hydrology. Elsevier, Amsterdam, pp. $51-86$.

McClelland JW, Valiela I. 1998. Linking nitrogen in estuarine producers to land-derived sources. Limnol. Oceanogr. 43: 577-585.

http://dx.doi.org/10.4319/lo.1998.43.4.0577 integran toda esa variabilidad y reflejan la señal isotópica resultante de todos estos procesos. Por otro lado, las propias macroalgas (y su condición) pueden pueden modificar la señal del $\mathrm{N}$. Entonces, para que el análisis de $\delta^{15} \mathrm{~N}$ en macroalgas sea una herramienta confiable en la evaluación de la contribución de cada fuente a un ecosistema, es necesario considerar todas las fuentes de variación. De otra manera, se puede llegar a conclusiones erróneas.

\section{Agradecimientos}

Este proyecto se realizó con fondos del proyecto UNAMPAPIIT IN206409. Los autores agradecen el apoyo en los trabajos de campo y de laboratorio a Humberto BojórquezLeyva, Arcelia Cruz-López y Roberto Velázquez-Ochoa. Agradecemos también a Yovani Montano-Ley y Victoria Montes-Montes la revisión del manuscrito, y a los dos revisores anónimos sus comentarios y sugerencias.

Middleburg JJ, Nieuwenhuize J. 2001. Nitrogen isotope tracing of dissolved inorganic nitrogen behavior in tidal estuaries. Estuar. Coast. Shelf Sci. 53: 385-391.

http://dx.doi.org/10.1006/ecss.2001.0805

Montaño-Ley Y, Peraza-Vizcarra R, Páez-Osuna F. 2008. Tidal hydrodynamics and their implications for the dispersion of effluents in Mazatlán Harbor: An urbanized shallow coastal lagoon. Water Air Soil Pollut. 194: 343-357. http://dx.doi.org/10.1007/s11270-008-9721-0

Moore JW, Semmens BX. 2008. Incorporating uncertainty and prior information into stable isotope mixing models. Ecol. Lett. 11: 470-480. http://dx.doi.org/10.1111/j.1461-0248.2008.01163.x

Mutchler T, Dunton KH, Townsend-Small A, Fredriksen S, Rasser MK. 2007. Isotopic and elemental indicators of nutrient sources and status of coastal habitats in the Caribbean Sea, Yucatan Peninsula, Mexico. Estuar. Coast. Shelf Sci. 74: 449-457. http://dx.doi.org/10.1016/j.ecss.2007.04.005

Nixon SW. 1995. Coastal eutrophication: A definition, social causes, and future concerns. Ophelia 41: 199-220.

Ochoa-Izaguirre MJ, Carballo JL, Páez-Osuna F. 2002. Qualitative changes in macroalgal assemblages under two contrasting climatic conditions in a subtropical estuary. Bot. Mar. 45: $130-138$. http://dx.doi.org/10.1515/BOT.2002.014

Ottosen M, Risgaard-Petersen N, Nielsen LP. 1999. Direct and indirect measurements of nitrification and denitrification in the rhizosphere of aquatic macrophytes. Aquat. Microbiol. Ecol. 19: 81-91.

Phillips DL, Gregg JW. 2003. Source partitioning using stable isotopes: Coping with too many sources. Oecologia 136: 261-269.

http://dx.doi.org/10.1007/s00442-003-1218-3

Piñón-Gimate A, Soto-Jiménez MF, Ochoa-Izaguirre MJ, GarcíaPagés E, Páez-Osuna F. 2009. Macroalgae blooms and $\delta^{15} \mathrm{~N}$ in subtropical coastal lagoons from the southeastern Gulf of California: Discrimination between agricultural, shrimp farm and sewage effluents. Mar. Pollut. Bull. 58: 1144-1151. http://dx.doi.org/10.1016/j.marpolbul.2009.04.004 
Ricaurte-Villota C, González-Yajimovich O, Sánchez A. 2013. Coupled response of rainfall and denitrification to solar forcing during the Holocene in Alfonso Basin. Cienc. Mar. 39: 151-164.

http://dx.doi.org/10.7773/cm.v39i2.2224

Savage C. 2005. Tracing the influence of sewage nitrogen in a coastal ecosystem using stable nitrogen isotopes. Ambio 34: $145-150$. http://dx.doi.org/10.1579/0044-7447-34.2.145

Sigman DM, Altabet MA, Michener R, McCorklr DC, Fry B, Holmes RM. 1997. Natural abundant-level measurement of the nitrogen isotopic composition of oceanic nitrate: An adaptation of the ammonia diffusion method. Mar. Chem. 57: 227-242. http://dx.doi.org/10.1016/S0304-4203(97)00009-1

Soto-Jiménez MF, Páez-Osuna F. 2001. Distribution and normalization of heavy metal concentrations in mangrove and lagoonal sediments from Mazatlán Harbor (SE Gulf of California). Estuar. Coast. Shelf Sci. 53: 259-274. http://dx.doi.org/10.1006/ecss.2000.0814

Soto-Jiménez MF, Páez-Osuna F, Bojórquez-Leyva H. 2003a. Nutrient cycling at the sediment-water interface and sediments at Chiricahueto marsh: A subtropical ecosystem associated with agricultural land uses. Water Res. 37: 719-728. http://dx.doi.org/10.1016/S0043-1354(02)00380-9

Soto-Jiménez M, Páez-Osuna F, Ruiz-Fernández AC. 2003b. Organic matter and nutrients in an altered subtropical marsh system, Chiricahueto, NW Mexico. Environ. Geol. 43: 913-921. http://dx.doi.org/10.1007/s00254-002-0711-z.

Spotte S, Adams G. 1983. Estimation of the allowable upper limit of ammonia in saline waters. Mar. Ecol. Prog. Ser. 10: 207-210.

Strickland JDH, Parsons TR. 1972. A Practical Handbook of Seawater Analysis. Fish. Res. Bd. Canada, Bull. 167, 311 pp.

Swart PK, Evans S, Capo T. 2008. The origin of nitrogen isotope values in algae. A research project conducted by the stable isotope laboratory. Technical Report EPA 20080501, University of Miami, $29 \mathrm{pp}$.

Valiela I, Collins G, Kremer J, Lajtha K, Geist M, Seely B, Brawley J, Sham CH. 1997. Nitrogen loading from coastal watersheds to receiving estuaries: New method and application. Ecol. Appl. 7: 358-380.

Valiela I, Bowen JL, Kroeger KD. 2002. Assessment of models for estimation of land-derived nitrogen loads to shallow estuaries. Appl. Geochem. 17: 935-953.

http://dx.doi.org/10.1016/S0883-2927(02)00073-2

Received January 2013,

received in revised form November 2013, accepted November 2013. 